medRxiv preprint doi: https://doi.org/10.1101/2021.06.30.21259750; this version posted July 5, 2021. The copyright holder for this preprint (which was not certified by peer review) is the author/funder, who has granted medRxiv a license to display the preprint in perpetuity. It is made available under a CC-BY-NC-ND 4.0 International license.

\title{
SARS-CoV-2 and the role of vertical transmission from infected pregnant women to their fetuses: systematic review
}

Annette Plüddemann ${ }^{1}$ Elizabeth A. Spencer ${ }^{1}$, Carl J. Heneghan ${ }^{1}$, Jon Brassey², Igho J. Onakpoya ${ }^{3}$, Elena Cecilia Rosca ${ }^{4}$, David H. Evans ${ }^{5}$, John M. Conly ${ }^{6}$, Tom Jefferson ${ }^{3}$.

Corresponding author: annette.pluddemann@phc.ox.ac.uk

1. University of Oxford, Centre for Evidence-Based Medicine, Nuffield Department of Primary Care Health Sciences, Oxford UK OX2 6GG

2. Trip Database Ltd, Glasllwch Lane, Newport, UK NP20 3PS

3. Department of Continuing Education, University of Oxford, Rewley House, 1 Wellington Square, Oxford OX1 2JA, UK

4. Victor Babes University of Medicine and Pharmacy, Piața Eftimie Murgu 2, Timișoara 300041, Romania

5. Li Ka Shing Institute of Virology and Dept. of Medical Microbiology \& Immunology, University of Alberta

6. Departments of Medicine, Microbiology, Immunology \& Infectious Diseases, and Pathology \& Laboratory Medicine, Synder Institute for Chronic Diseases and O'Brien Institute for Public Health, Cumming School of Medicine, University of Calgary and Alberta Health Services, Calgary, Canada.

\section{Abstract \\ Background}

Vertical transmission of SARS-CoV-2 has been reported but does not appear to be common. This study aims to systematically review the evidence for vertical transmission of SARS-CoV-2.

\section{Methods}

This review is part of an Open Evidence Review on the transmission dynamics of SARS-CoV-2 and the role of intrauterine mother to fetus transmission. Literature searches were performed in the WHO Covid-19 Database, LitCovid, medRxiv, and Google Scholar for SARS-CoV-2 using keywords and associated synonyms, search date up to 20 December 2020, no language restrictions.

\section{Results}

We included 106 studies assessing vertical transmission of SARS-CoV-2 from pregnant women to their neonates: these studies comprised 40 reviews ( 21 fulfilled systematic review methodology, including risk of bias assessment of included studies) and 66 primary studies including 32 case reports (of up to two cases) and 34 prospective and retrospective cohort studies, prospective and retrospective case series, observational studies (including asymptomatic screening), database studies and a quality improvement project. Almost all were conducted in a hospital setting. The 32 case reports were considered to be at high risk of bias, due to the study design; across the 34 remaining primary studies, risk of bias was low to moderate. Sixteen case reports examined vertical transmission, which was not related to maternal symptomatology. For the cohort and case series studies, the percentage of positive neonates ranged from $0 \%$ to $22 \%$ across the studies. Twenty studies reported no positive vertical transmission. Three studies that reported the highest positivity

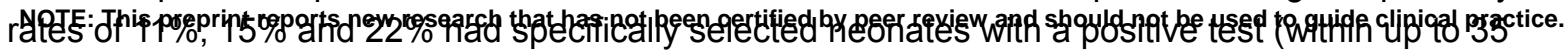


medRxiv preprint doi: https://doi.org/10.1101/2021.06.30.21259750; this version posted July 5, 2021. The copyright holder for this preprint (which was not certified by peer review) is the author/funder, who has granted medRxiv a license to display the preprint in perpetuity. It is made available under a CC-BY-NC-ND 4.0 International license.

days) within the study population and were therefore more selective populations. Across the cohort and case series studies there were 65/2391 (2.7\%) neonates born to mothers with a diagnosis of COVID-19 tested positive for SARS-CoV-2 within 24 hours of birth. No evidence correlated maternal symptomatology to vertical transmission. Mode of delivery did not correlate with rates of vertical transmission. Of 25 studies, 7 identified SARS-CoV-2 in placental tissue; some of these did not demonstrate vertical transmission to the neonate. No study reported the results of viral culture to detect SARS-CoV-2.

\section{Conclusions}

The results of these studies indicate that vertical transmission is possible, but is not frequent, and factors that influence when vertical transmission occurs are unknown. Further studies using standardised methods to establish viral infection are needed to establish vertical transmission rates and to assess clinical and other conditions affecting transmission. 
medRxiv preprint doi: https://doi.org/10.1101/2021.06.30.21259750; this version posted July 5, 2021. The copyright holder for this preprint (which was not certified by peer review) is the author/funder, who has granted medRxiv a license to display the preprint in perpetuity. It is made available under a CC-BY-NC-ND 4.0 International license.

\section{Background}

Research on previous coronavirus outbreaks of the Middle East respiratory syndrome coronavirus (MERS-CoV) in 2012 and the severe acute respiratory syndrome coronavirus (SARS-CoV) in 2002-2003, assessed the risk of vertical transmission from infected mothers to their neonates and to date no cases of vertical transmission were reported ${ }^{1,2}$. For SARS-CoV-2, several studies have assessed vertical transmission with some early reviews reporting no evidence of vertical transmission ${ }^{3,4}$, while others reported that vertical transmission was possible and could not be ruled out ${ }^{4,5}$ although the risk appeared to be low ${ }^{6}$. This study therefore aims to systematically review the evidence for vertical transmission of SARS-CoV-2.

A WHO scientific brief ${ }^{2}$, published in February 2021, based on an evidence synthesis and expert consultation, considered three mechanisms of vertical transmission: (1) in utero, where the virus is present in the blood and crosses the maternal-placental interface; (2) intrapartum, occuring during labour and childbirth via contact with maternal blood, vaginal secretions or faeces; and (3) postnatal, via breast milk but can include contact with an infected mother, another infected caregiver or fomites. The WHO review highlighted that defining vertical transmission of SARS-CoV-2 has been challenging, as much of the reported vertical transmission has been based on a single positive neonatal RT-PCR in an upper respiratory tract specimen, with significant variation in the timing of sample collection. A proposed definition of confirmed in utero transmission was considered to be a positive RT-PCR test in one or more neonatal samples (including neonatal blood, respiratory swab, stool sample), amniotic fluid or a placental tissue sample; or positive serology, at age $<24$ hours, where there was evidence of maternal SARS-CoV-2 infection during pregnancy. Another study ${ }^{7}$ proposed a definition for vertical transmission as including a positive SARS-CoV-2 test in neonates in the first $24 \mathrm{~h}$ of life (including respiratory tract swab, neonatal blood, cord blood or amniotic fluid) from mothers who had tested positive for SARS-CoV-2 between 14 days prior to birth and 2 days after birth. The UK Obstetric Surveillance System (UKOSS), however, defined vertical transmission as a positive neonatal sample taken within the first $12 \mathrm{~h}$ following birth to a mother with confirmed SARS-CoV-2 infection ${ }^{8}$. Given the challenges in defining vertical transmission and that many studies do not report what criteria were applied to define vertical transmission, in the current review, vertical transmission was considered as a positive test in the neonate (including RT-PCR testing of respiratory tract swabs, blood samples, placenta, amniotic fluid) at birth or up to $24 \mathrm{~h}$ of life, where the mother had either tested positive for SARS-CoV-2 or had a recorded diagnosis of COVID-19.

\section{Definition}

Vertical transmission: positive test for SARS-CoV-2 in a neonate up to 24 hours of life, including RT-PCR testing of respiratory tract swab samples, fecal samples, blood samples, placenta tissue, amniotic fluid samples, where the mother had a positive test for SARS-CoV-2 or a recorded diagnosis of COVID-19 
medRxiv preprint doi: https://doi.org/10.1101/2021.06.30.21259750; this version posted July 5, 2021. The copyright holder for this preprint (which was not certified by peer review) is the author/funder, who has granted medRxiv a license to display the preprint in perpetuity. It is made available under a CC-BY-NC-ND 4.0 International license .

\section{Methods}

We are undertaking an open evidence review investigating factors and circumstances that impact on the transmission of SARS-CoV-2, based on our published protocol last updated on 1 December 2020 (Supplementary files, Protocol). This review aims to identify, appraise, and summarize the evidence (from peer-reviewed studies or studies awaiting peer review) assessing the occurrence of vertical transmission of SARS-CoV-2 from mothers to their babies in utero. We are conducting an ongoing literature search in the WHO Covid-19 Database, LitCovid, medRxiv, and Google Scholar for SARS-CoV-2 for keywords and associated synonyms. The search for this review was conducted up to 20 December 2020. We did not impose any language restrictions. (See Supplementary files for the search strategies).

Studies of any design (including reviews and case reports) reporting vertical transmission were included. For the included primary studies, the risk of bias was assessed using five domains from the QUADAS-2 criteria 9; we adapted this tool because the included studies were not primarily designed as diagnostic accuracy studies. Due to the intrinsic difference in study designs, we did not conduct a quality appraisal of case reports reporting on only one or up to two cases, and data from these studies is reported separately in the Results. We checked the methodology of included reviews and recorded whether they fulfilled systematic review methodology; we did not perform formal assessments of the quality of included systematic reviews but summarized their findings, including quality of their included studies as reported by the authors. We extracted the following information from included primary studies: the country, setting and included population; study design; symptoms reported in mothers (including timing of symptoms if reported); the mode of delivery of babies (if reported); sample sources for SARS-CoV-2 testing for mothers and babies and SARS-CoV-2; and the numbers of neonates testing positive for SARS-CoV-2 from mothers with a COVID-19 positive diagnosis, as well as live culture results and any other relevant results (e.g. assessment of the placenta using histopathology and /or culture and/or immunostaining). We also extracted information on methodology used for RT-PCR, cycle threshold (Ct), and viral culture if reported. We defined "vertical transmission" as a positive test in the neonate within $24 \mathrm{~h}$ of life, unless otherwise stated.

One reviewer (EAS) assessed the risk of bias from the primary studies (cohort and case series with > 2 cases) and these judgments were independently verified by a second reviewer (AP). Two reviewers (AP and EAS) extracted data from the included primary studies (including the case reports), each extracting data from half of the studes and independently verifying the data extraction of the other studies. One reviewer (AP) extracted data from the included systematic reviews, and these were independently checked by a second reviewer (EAS). Disagreements in the data extraction or bias assessments were resolved by consensus. A third author (IJO) was available in case consensus could not be reached. Results are presented in tabular format and a bar chart was used to represent the percentage of neonates testing positive for SARS-CoV-2 within $24 \mathrm{~h}$ of birth: these were neonates born to mothers with a SARS-CoV-2 positive test or with a recorded COVID-19 diagnosis which included imaging or X-ray. We did not conduct meta-analysis because of substantial heterogeneity across the included studies.

\section{Results}

We found 123 studies assessing vertical transmission of SARS-CoV-2 from pregnant women to their neonates (Figure 1. PRISMA flow diagram). The studies assessed included 40 reviews and 83 primary studies. Laboratory studies, studies on breast milk only, one study describing a spa outbreak 
medRxiv preprint doi: https://doi.org/10.1101/2021.06.30.21259750; this version posted July 5, 2021. The copyright holder for this preprint (which was not certified by peer review) is the author/funder, who has granted medRxiv a license to display the preprint in perpetuity. It is made available under a CC-BY-NC-ND 4.0 International license.

that did not report data for pregnant women, two case reports that did not provide data for testing of the baby, one study on oocytes, and one study that reported a subset of data of another included study ${ }^{10}$ were excluded (see Supplementary files, List of excluded studies). After removing duplicates we included a total of 106 studies: 40 reviews and 66 primary studies.

Amongst the 66 primary studies or reports (see Supplementary files, Table 1a. Characteristics of included studies), 32 were case reports (describing either single cases only or up to 2 cases) and the remaining 34 studies included prospective and retrospective cohort studies, prospective and retrospective case series, observational studies (including asymptomatic screening), database studies and a quality improvement project. Most studies reported results from testing of neonates, however one cohort study (Smithgall MC 2020) and one case series (Zhang P 2020) reported only on placental samples. Forty eight primary studies reported testing respiratory samples in neonates; in 10 studies the neonatal sample source was not clearly reported; the remainder of the studies examined placental, amniotic, umbilical and skin swab samples. The main findings of the included primary studies and systematic reviews are shown in Supplementary files Table $1 \mathrm{~b}$. Main findings of included primary studies and Table 1c. Main findings of included reviews.

\section{Quality of the evidence}

We assessed the methodology of included reviews and documented whether they fulfilled systematic review methodology; we did not otherwise assess their quality. Of 40 reviews, 21 fulfilled systematic review methodology, including risk of bias assessment of included studies; the others are considered narrative reviews. We did not assess the quality of case reports and we did not formally assess the quality of the reviews. The risk of bias of the included primary studies is shown in Table 2. Quality of included primary studies. Almost all studies adequately reported the methods to allow replication of the study with only 5 studies rated as unclear in this domain (although it is to be noted that laboratory testing methods reporting was significantly limited as outlined below). One study did not report information on sample sources and six studies were rated as unclear in this domain, with $5 / 6$ of these studies not reporting the sample sources used for SARS-CoV-2 testing from the mothers, and one not reporting the sample source for the neonates. Analysis and reporting was appropriate for almost all studies with only $2 / 34$ rating as unclear in this domain. Bias was not addressed in 27/34 studies and only 2 studies specifically addressed bias, with the remainder having an unclear rating. We judged the overall risk of bias across the 32 case reports as high; the overall risk of bias across the remaining 34 studies was low to moderate. It is also notable that almost all studies were conducted in a hospital setting and thus only women attending hospital were included in these studies, which may introduce bias regarding the included population in terms of presenting for rapid and accessible SARS-CoV-2 testing, as well as understanding vertical transmission in the out-of-hospital setting.

\section{Reviews}

We included 40 reviews assessing the possibility of vertical maternal-fetal transmission of SARS-CoV-2 (Supplementary file Table 1c. Main findings of included reviews). Half (21/40) of the reviews applied at least some systematic review methodology, including appraisal of the risk of bias of included studies, while the remaining reviews were narrative reviews or literature overviews. The systematic review with the most recent search date, up to 31 October 2020, included 70 studies with a total of 1457 pregnant women diagnosed with COVID-19 (Amaral W 2020). This review identified 21 studies including 39 (3.7\%) newborns who tested positive for SARS-CoV-2, and reported the detection of SARS-CoV-2 RNA in the placenta $(n=13)$. However, only 6 studies in the review reported positive tests for newborns within $24 h(n=13$ cases, $<1 \%)$. The majority $(n=58)$ of the included studies in the review were judged by the authors to be of low or very low quality using the 
medRxiv preprint doi: https://doi.org/10.1101/2021.06.30.21259750; this version posted July 5, 2021. The copyright holder for this preprint (which was not certified by peer review) is the author/funder, who has granted medRxiv a license to display the preprint in perpetuity. It is made available under a CC-BY-NC-ND 4.0 International license.

GRADE quality of evidence assessment, with only one included cohort study judged to be of high quality. Overall 21 reviews (Amaral W 2020, Bellos I 2020, Bwire GM 2020, Caparros-Gonzalez RA 2020, Cavalcante de Melo 2020, Chi J 2020, Deniz M 2020, Dhir SK 2020, Di Toro F 2020, Dube R 2020, Goh XL 2020, Khalil A 2020, Kotlyar AM 2020, Pettirosso E 2020, Raschetti R 2020, Rodriques C 2020, Romeo G 2020, Sheth S 2020, Tripella G 2020, Turan O 2020, Walker KF 2020) found evidence of vertical transmission, reporting transmission rates between $1 \%$ and $5 \%$. Fifteen reviews did not find any evidence for vertical transmission (using a broader definition of vertical transmission including peribirth and post birth), although some stated vertical transmission could not be ruled out despite the lack of evidence (Abd EW 2020, Akhtar H 2020, AlQahtani MA 2020, Della Gatta AN 2020, Diriba K 2020, Gao Y 2020, Han Y 2020, Hessami K 2020, Huntley BJF 2020, Juan J 2020, Novoa RH 2020, Sampieri CL 2020, Shrestha R 2020, Thomas P 2020, Yoon SH 2020). However, for the majority of these reviews, the search end date was until April 2020 or May 2020, with the latest search date being July 2020 for one non-systematic review (Hessami K 2020). The remaining reviews did not specifically report vertical transmission rates. One review reported data solely on transmission via breast milk (Centeno-Tablante E 2020) and found no evidence of SARS-CoV-2 transmission through breast milk. Two reviews focused specifically on maternal characteristics and clinical outcomes and reported that pregnant women did not appear to be more affected by the respiratory complications of COVID-19, compared with non-pregnant women (Fiqueiro-Filho EA 2020) and that SARS-CoV-2 infection was not specifically shown to increase the risk of maternal, fetal, and neonatal complications (Salem D 2020), although other included reviews have reported the potential for higher risk of complications, depending on the maternal disease course (Amaral W 2020). One review assessed diagnostic methodologies to determine vertical transmission, finding a lack of consensus on the diagnostic strategy for congenital infection (Mahyuddin AP 2020).

\section{Case reports}

There were 32 case reports included in this review, of which 28 reports were of single cases and 4 reports included 2 cases. Sixteen case reports reported vertical transmission, with babies testing positive for SARS-CoV-2 by RT-PCR within $24 \mathrm{~h}$, while 13 did not find vertical transmission (Supplementary file Table 1b. Main findings of included primary studies). Three studies did not report results for testing of neonates: three assessed amniotic fluid samples from SARS-CoV-2 PCR positive women only due to death of the fetus, with 2 reporting the presence of SARS-CoV-2 RNA using PCR in amniotic fluid and placental cell supernatant (Shende P 2020, 1 case; Pulinx B 2020, 2 cases) and one reporting a negative test for SARS-CoV-2 RNA (Rubio Lorente AMR 2020). The symptom status of the mother did not directly correlate with whether the baby tested positive, as some asymptomatic women were reported to have a neonate who tested positive for SARS-CoV-2.

\section{Primary studies}

We included 34 primary studies that were not case reports. The primary studies included eight case series (Chaudhary S 2020, Liu W 2020, Masmejan S 2020, Olivini N 2020, Pereira A 2020, Pissarra S 2020, Zhang L 2020, Zhang P 2020), 21 cohort studies (either prospective or retrospective) (Anand P 2020, Ayed A 2020, Bachani S 2020, Barbero P 2020, Gale C 2020, Fenizia B 2020, He Z 2020, Hu X 2020, Luo Q 2020, Khan MA 2020, Nayak AH 2020, Ogamba I 2020, Oncel MY 2020, Maraschini A 2020, Popofsky S 2020, Schwartz DA 2020, Smithqall MC 2020, Tang F 2020, Vinuela MC 2020 , Vouga M 2020,Yang R 2020), 2 retrospective observational studies (Gao X 2020, Moreno SC 2020). and one quality improvement project (Cojocaru L 2020), one longitudinal surveillance study (Woodworth KR 2020), and one multi-centre retrospective chart review (Marin Gabriel MA 2020. Across these primary studies we extracted the data reporting the number of neonates testing positive 
medRxiv preprint doi: https://doi.org/10.1101/2021.06.30.21259750; this version posted July 5, 2021. The copyright holder for this preprint (which was not certified by peer review) is the author/funder, who has granted medRxiv a license to display the preprint in perpetuity. It is made available under a CC-BY-NC-ND 4.0 International license.

for SARS-CoV-2 by RT-PCR within $24 \mathrm{~h}$ of birth (typically from a nasopharyngeal swab), who were born to mothers who either had a positive test for SARS-CoV-2 (RT-PCR or serologic testing) or who were diagnosed as having COVID-19 based on clinical assessment including imaging or chest X-ray. Twenty studies reported no positive neonatal cases for neonates tested within 24h of birth (Table 3 . Main findings of included cohort and case series studies, Figure 2). Two studies reporting the higher percentage of SARS-CoV-2 cases amongst neonates ( $22 \%$ and $11 \%)$ were cohort studies that had specifically selected only neonates with a positive test within 28 days (Gale C 2020) or within 35 days (Schwartz DA 2020) of birth as the included population, where some but not all had been born to mothers with known SARS-CoV-2 infection. These therefore constituted a selected population. The study reporting $15 \%$ positivity for neonates was a small study $(n=20)$ including neonates with a positive SARS-CoV-2 test (antibody or RT-PCR) within 14 days after birth or mothers with a positive COVID-19 test in the third trimester (Tang F 2020). These latter studies therefore also constitute a more selected population. The remaining studies reported percentages of positive neonates between $0.8 \%$ and $10.8 \%$. Overall there were a total of 2391 neonates included in the analysis of which 65 $(2.7 \%)$ had a positive RT-PCR test for SARS-CoV-2 within $24 \mathrm{~h}$ of birth.

The studies included symptomatic and asymptomatic women; however there did not seem to be a specific correlation between symptom status of the mothers and the likelihood of a positive test in the babies, with some studies reporting on women who had symptoms of COVID-19 either immediately prior to or during hospitalisation, some with severe symptoms, where none of the babies tested positive within 24h of birth (e.g. Liu W 2020, Luo Q 2020, Masmejan S 2020, Moreno SC 2020, Ogamba I 2020, Popofsky S 2020) (See Table 1a). Similarly, the mode of delivery (vaginal birth, caesarean section, emergency caesarean section) did not seem to be correlated to positivity rate amongst neonates; across the included cohort and case series studies, for the 6188 cases where mode of delivery was reported, 3939 were by vaginal delivery, 2122 by caesarean section, and 127 reported as emergency caesarean (Table $1 \mathrm{~b}$ ). The overall rate of caesarean section across the included studies thus appears higher than rates generally reported, for example in the UK a recent study reported the rate of caesarean section delivery to range from $13.6 \%$ to $31.9 \%$ across 146 English NHS trusts ${ }^{11}$, although rates may be context dependent. This may relate to a cautious approach being taken, particularly in the early stages of the pandemic where there was a lack of evidence to inform practice. As noted by others it is reasonable to question whether caesarean delivery for pregnant patients with COVID-19 as the indication, is warranted (Della Gatta AN 2020).

We considered mothers' test results up to 5 days pre delivery and 8 days post delivery, and mothers' symptomatology in that same time period (as the relevant time period of likely infectiousness). We also looked at studies' reports of SARS-CoV-2 testing in the neonates up to or at 24 hours of life, as the most relevant indicator of possible vertical transmission. Testing in mothers was not reported in 4 studies; timing for the mothers' testing was not reported in 23/79 studies, and the timing was unclear in 1 study. Timing of mothers' symptomatology was not reported or unclear in 28/83 studies. 75/83 studies reported testing of neonates within 24 hours of life for SARS-CoV-2: among these 75 studies, 144 neonates $/ 1,545$ total neonates tested positive within $24 \mathrm{~h}$ of life. Among those neonates with a positive testing mother within 5 days pre delivery and 8 days post delivery, the number of neonates testing positive was $19 / 199$. For neonates of women with a positive test and symptoms within that time window, $13 / 32$ neonates tested positive within $24 \mathrm{~h}$ of life. The number of neonates with a positive test within 24 hers, born to women with a negative test within 5 days pre and 8 days post delivery, was 4 of 5 neonates.

The focus of this review was to assess the evidence for vertical transmission and did not specifically address the question of maternal and fetal outcomes. Other reviews addressing this question have concluded that SARS-CoV-2 infection was not specifically shown to increase the risk of maternal, 
medRxiv preprint doi: https://doi.org/10.1101/2021.06.30.21259750; this version posted July 5, 2021. The copyright holder for this preprint (which was not certified by peer review) is the author/funder, who has granted medRxiv a license to display the preprint in perpetuity. It is made available under a CC-BY-NC-ND 4.0 International license.

fetal, and neonatal complications (Salem D 2020), although some reviews have reported the potential for higher risk of complications, depending on the maternal disease course (Amaral W 2020). The cohort and case series studies in this review reported some cases of neonatal admission to intensive care, but this was not always related to symptoms of SARS-CoV-2 and several studies reported no symptoms in neonates who had tested positive for SARS-CoV-2 (Table 3. Main findings of included cohort and case series studies).

\section{Detection of virus in the placenta using PCR and immunostaining}

Of the included studies, 25 studies reported assessment of the placenta, of these 18 were case studies (Alamar I 2020, Birindwa EK 2020, Ferraiolo A 2020, Grimminck K 2020, Kulkarni R 2020, Hsu AL 2020, Lv Y 2020, Palalioglu RM 2020, Pulinx B 2020, Rebello CM 2020, Shende P 2020, Sisman J 2020, Stonoga E 2020, Tang J 2020, Vivanti AJ 2020, Von Kohorn I 2020, Zaigham M 2020. Zheng T 2020), 2 were retrospective case series (Liu W 2020, Masmejan S 2020), 3 were cohort studies (Fenizia B 2020, Ogamba I 2020, Oncel MY 2020) and 2 were a cohort and a case series specifically studying placental samples (Smithgall MC 2020, Zhang P 2020) (Supplementary file Table 4. Findings of studies reporting placenta analysis). Seven studies reported placentas testing positive for SARS-CoV-2 by in situ hybridisation or immunohistochemistry (Alamar I 2020, Hsu AL 2020,

Pulinx B 2020, Shende P 2020, Vivanti AJ 2020, Zaigham M 2020, Zhang P 2020), although not all of these reported vertical transmission to the neonate. Some studies only tested placentas for the presence of SARS-CoV-2 by RT-PCR and did not perform histopathology, while others assessed general inflammation of the placenta, but did not conduct immunostaining for viral presence (Supplementary file Table 4. Findings of studies reporting placenta analysis). One case study conducted whole genome sequencing of viral samples from the mother, placenta and neonate and reported the presence of a single variant of the virus in the mother and placenta. Interestingly, the neonate displayed a SARS-CoV-2 population which included the strain identical to that identified in the mother and placenta, as well as a population with one single-nucleotide polymorphism difference, and they are probably the same strain. This suggests vertical transmission for this case and the potential for a minor intrapatient genetic drift (Zaigham M 2020).

\section{SARS-CoV-2 testing methodology}

None of the included studies reported results of viral culture to detect SARS-CoV-2 (Supplementary file Table $5 \mathrm{Ct}$ counts and RNA concentration results of included studies). All studies used RT-PCR (alone or in combination with clinical and/or immunologic tests) to determine the presence of SARS-CoV-2 infection in the mothers and the babies. However, the majority of studies did not report details of the methods used nor did they report Ct values. Fourteen studies reported RT-PCR methodological information, including the gene probes used (Anand P 2020, Bachani S 2020, Demiriian A 2020, Fenizia B 2020, Gao X 2020, Hinojosa-Velasco A 2020, Luo Q 2020, Pulinx B 2020, Shende P 2020, Tang F 2020, Vinuela MC 2020, Vivanti AJ 2020, Von Kohorn I 2020, Zaigham $\underline{\mathrm{M}} 2020$ ), although only 9 studies reported the cycle threshold (Ct) with reported $\mathrm{Ct}$ ranging from 13-41 (Bachani S 2020, Demiriian A 2020, Hinojosa-Velasco A 2020, Pulinx B 2020, Shende P 2020, Vinuela MC 2020, Vivanti AJ 2020, Von Kohorn I 2020, Zaigham M 2020). Two studies provided an estimate of viral load based on RT-PCR Ct (Bachani S 2020, Hinojosa-Velasco A 2020), citing a Ct of 15 and 23, respectively, as "high viral load", and one study reported the viral load of each sample, expressed as log copies/mL or per million of cells as appropriate (Vivanti AJ 2020). 
medRxiv preprint doi: https://doi.org/10.1101/2021.06.30.21259750; this version posted July 5, 2021. The copyright holder for this preprint (which was not certified by peer review) is the author/funder, who has granted medRxiv a license to display the preprint in perpetuity. It is made available under a CC-BY-NC-ND 4.0 International license.

\section{Discussion}

We identified 40 reviews and 66 primary studies assessing vertical transmission of SARS-CoV-2 from pregnant women to their neonates. Overall, the results of these studies indicate that vertical transmission is possible, but is not frequent, and factors affecting whether vertical transmission occurs are unknown. The analysis of the included primary studies that were not case reports found that overall of the 2391 included neonates, $65(2.7 \%)$ had a positive RT-PCR test for SARS-CoV-2 within $24 \mathrm{~h}$ of birth; this may not be a representative population of pregnant women and neonates. Other systematic reviews included in this study have reported similar results, for example Amaral W 2020 reported a positivity rate for newborns within $24 \mathrm{~h}$ of less than $1 \%$, Cavalcante de Melo 2020 reported $2 \%$ positivity rate and Dhir SK 2020 reported $5 \%$ positivity rate. When considering other viruses or microbial pathogens known to be transmitted from mothers to infants, a systematic review of mother-to child transmission of HIV including 18 studies and 6253 participants reported an estimated pooled prevalence of mother-to-child transmission of $\mathrm{HIV}$ of $11.4 \%(95 \% \mathrm{CI}=9.1-13.7)^{12}$; a systematic review of vertical transmission of chikungunya virus including 42 studies and 266 infected neonates reported a vertical transmission rate of $50 \%{ }^{13}$; and a retrospective analysis of mid-trimester amniocentesis performed in pregnancies with diagnosed maternal infection by cytomegalovirus (CMV), rubella or Toxoplasma gondii reported a transmission rate of $17.3 \%$ in cases with infection from CMV, 9.5\% from Toxoplasma gondii and $7.8 \%$ from rubella ${ }^{14}$.

All of the included studies in this review used RT-PCR (alone or in combination with clinical and/or immunologic tests) to determine the presence of SARS-CoV-2 infection in the mothers and neonates, but most studies did not report details of the PCR methods used nor did they report Ct values. Notably none of the studies reported results of viral culture to detect SARS-CoV-2 and only one case report conducted whole genome sequencing of viral samples from the mother and neonate, reporting the presence of a single variant of the virus, indicating vertical transmission (Zaigham M 2020). In addition, in most studies no definition was provided as to what constituted "vertical transmission" and the maternal disease course was not always described in relation to testing, therefore it is possible that some cases identified as vertical transmission in the included studies could have been attributable to an alternative source of infection.

The majority of studies utilised PCR testing to assess vertical transmission. Whilst these studies suggest that vertical transmission is possible and may occur in a minority of pregnancies, these data in themselves can not discern whether infection takes place in utero, during the birth process, or via contact with the mother or health care workers at or shortly after birth.

This review did not specifically assess maternal and fetal outcomes. Some early reviews that have assessed this question found that SARS-CoV-2 infection was not specifically shown to increase the risk of maternal, fetal, and neonatal complications (Salem D 2020), while others have reported the potential for higher risk of complications for both mothers and their neonates, depending on the maternal disease course (Amaral W 2020). One recent large multinational cohort study assessing maternal and neonatal morbidity and mortality, comparing pregnant women with and without a COVID-19 diagnosis, found higher rates of adverse outcomes, including maternal mortality, preeclampsia, and preterm birth, in women with COVID-19 (Villar et al 2021) and this warrants further investigation.

The presence of positive tests in both mother and neonate does not unequivocally demonstrate direct transfer of virus from mother to neonate, nor can it demonstrate the biological process by which virus may be transferred. For neonates testing positive for SARS-CoV-2, the virus may have been transmitted directly from mother to neonate across the placenta, but other infection routes may also 
medRxiv preprint doi: https://doi.org/10.1101/2021.06.30.21259750; this version posted July 5, 2021. The copyright holder for this preprint (which was not certified by peer review) is the author/funder, who has granted medRxiv a license to display the preprint in perpetuity. It is made available under a CC-BY-NC-ND 4.0 International license .

occur. For example, one study examining fecal samples of mother-neonate dyads found that although the majority of the bacterial microbiome mirrored that of the mother, only a small proportion of the virus population found in a neonate's fecal samples matched that of the mother. This would be expected given that the gut flora in neonates will be very different from the mother, but this also suggests virus transfer via other routes such as skin contact, breastmilk, or local contamination (Maqsood et al 2019).

Evidence of SARS-CoV-2 RNA in placental samples does not demonstrate placental infection by the virus, nor that transmission via the placental barrier has occurred or can potentially occur (Wastnedge et al 2020). In these studies, positive PCR for SARS-CoV-2 in placentas did not necessarily correlate with positive PCR tests of the neonate. Some studies however showed intervillositis in the placenta and positive immunostaining for SARS-CoV-2 (Pulinx B 2020, Shende P 2020, Vivanti AJ 2020, Zaigham M 2020), which suggests the presence of SARS-CoV-2 in the placenta, and recent work has reported cultivatable SARS-CoV-2 from placental tissue with positive histopathology and whole genome sequencing supporting true vertical transmission (Vayalumkal et al 2021). Overall, viral invasion of the placenta appears to be likely, given the reports in some studies of intervillositis in the placenta and positive immunostaining for SARS-CoV-2; however more high quality information is needed for a clearer understanding of placental infection, the possibility of the virus being transmitted via the placental barrier, and the risk of transmission at the different stages of pregnancy. Nonetheless the demonstration in multiple studies of intervillositis in the placenta and positive immunostaining for SARS-CoV-2 would be strong enough evidence to suggest policy development against placentophagy in the setting of a mother who delivers and has active SARS-CoV-2 infection.

\section{Strengths and limitations of the study}

We conducted a comprehensive search of the literature on vertical transmission of SARS-CoV-2, also including studies that had not yet undergone peer review. We also accounted for the reporting quality of included primary studies. However, we may have missed some relevant studies and recognise that several studies may have been published after December 2020, which was the end date for the search. For example, there may now be more high quality cohort studies as much of the early evidence, as identified in this review, constituted single case studies. The aim of this review was to assess the evidence for vertical transmission and we did not specifically address maternal and fetal outcomes as a primary outcome measure. We did not systematically search for studies reporting this in our review and any conclusions around maternal and fetal outcomes should be interpreted with caution. The definition of vertical transmission varied across studies, with many not reporting the definition of vertical transmission used in the study. It should also be noted that all studies were conducted in the hospital setting, therefore this review does not provide evidence regarding transmission in the out-of-hospital setting.

It is also well known that sample contamination is a hazard of performing PCR testing which is sufficiently sensitive to detect very low concentrations of nucleic acids; for example, to avoid contamination, a study of vertical transmission of HPV used separate buildings for collecting and testing samples (Smith et al 2010). To reduce uncertainty about transmission based on evidence from PCR testing alone, steps for avoiding contamination should be clearly performed and reported. In the studies reviewed here, we found little data relating to PCR procedures and so are unable to evaluate any potential risk of contamination. 
medRxiv preprint doi: https://doi.org/10.1101/2021.06.30.21259750; this version posted July 5, 2021. The copyright holder for this preprint (which was not certified by peer review) is the author/funder, who has granted medRxiv a license to display the preprint in perpetuity. It is made available under a CC-BY-NC-ND 4.0 International license .

\section{Implications for further research}

Evidence of replicable virus as indicated by serial culture with confirmed virus identification, along with concordance in the results of whole genome sequencing for samples from mother and neonate, would substantially reduce uncertainty about the mode of transmission ${ }^{15}$.

Whilst this currently available evidence suggests that vertical transmission is possible and appears to take place infrequently, there is very little information to explain what affects transmission, and therefore how risk can best be mitigated. The risk of vertical transmission is also uncertain when the SARS-CoV-2 infection occurs in the first or second trimester (especially if the mother is asymptomatic). Prospective studies are needed to recruit pregnant women and follow the perinatal and neonatal time course, collecting clinical and exposure information at multiple stages and utilising standardised methods to identify viral infection.

\section{Conclusion}

In conclusion, this review found evidence that vertical transmission can occur, but does not happen frequently. Among neonates born to women with a SARS-CoV-2 positive test or a recorded COVID-19 diagnosis, the great majority do not test positive for SARS-CoV-2 within the first 24 hours of life, indicating a low rate of vertical transmission. From the data we examined, it is not possible to establish what factors may affect vertical transmission.

\section{Competing Interests}

TJ was in receipt of a Cochrane Methods Innovations Fund grant to develop guidance on the use of regulatory data in Cochrane reviews (2015-018). In 2014-2016, he was a member of three advisory boards for Boehringer Ingelheim. TJ was a member of an independent data monitoring committee for a Sanofi Pasteur clinical trial on an influenza vaccine. TJ is occasionally interviewed by market research companies about phase I or II pharmaceutical products for which he receives fees (current). TJ was a member of three advisory boards for Boehringer Ingelheim (2014-16). TJ was a member of an independent data monitoring committee for a Sanofi Pasteur clinical trial on an influenza vaccine (2015-2017). TJ is a relator in a False Claims Act lawsuit on behalf of the United States that involves sales of Tamiflu for pandemic stockpiling. If resolved in the United States favor, he would be entitled to a percentage of the recovery. TJ is coholder of a Laura and John Arnold Foundation grant for development of a RIAT support centre (2017-2020) and Jean Monnet Network Grant, 2017-2020 for The Jean Monnet Health Law and Policy Network. TJ is an unpaid collaborator to the project Beyond Transparency in Pharmaceutical Research and Regulation led by Dalhousie University and funded by the Canadian Institutes of Health Research (2018-2022). TJ consulted for Illumina LLC on next generation gene sequencing (2019-2020). TJ was the consultant scientific coordinator for the HTA Medical Technology programme of the Agenzia per i Servizi Sanitari Nazionali (AGENAS) of the Italian MoH (2007-2019). TJ is Director Medical Affairs for BC Solutions, a market access company for medical devices in Europe. TJ was funded by NIHR UK and the World Health Organization (WHO) to update Cochrane review A122, Physical Interventions to interrupt the spread of respiratory viruses. TJ is funded by Oxford University to carry out a living review on the transmission epidemiology of COVID-19. Since 2020, TJ receives fees for articles published by The Spectator and other media 
medRxiv preprint doi: https://doi.org/10.1101/2021.06.30.21259750; this version posted July 5, 2021. The copyright holder for this preprint (which was not certified by peer review) is the author/funder, who has granted medRxiv a license to display the preprint in perpetuity. It is made available under a CC-BY-NC-ND 4.0 International license .

outlets. TJ is part of a review group carrying out Living rapid literature review on the modes of transmission of SARS-CoV-2 (WHO Registration 2020/1077093-0). He is a member of the WHO COVID-19 Infection Prevention and Control Research Working Group for which he receives no funds. $\mathrm{TJ}$ is funded to co-author rapid reviews on the impact of Covid restrictions by the Collateral Global Organisation. $\mathrm{He}$ is also an editor of the Cochrane Acute Respiratory Infections Group.

TJ's competing interests are also online https://restoringtrials.org/competing-interests-tom-jefferson

$\mathrm{CH}$ holds grant funding from the NIHR, the NIHR School of Primary Care Research, the NIHR BRC Oxford and the World Health Organization for a series of Living rapid review on the modes of transmission of SARs-CoV-2 reference WHO registration No2020/1077093. He has received financial remuneration from an asbestos case and given legal advice on mesh and hormone pregnancy tests cases. He has received expenses and fees for his media work including occasional payments from BBC Radio 4 Inside Health and The Spectator. He receives expenses for teaching EBM and is also paid for his GP work in NHS out of hours (contract Oxford Health NHS Foundation Trust). He has also received income from the publication of a series of toolkit books and for appraising treatment recommendations in non-NHS settings. He is Director of CEBM, an NIHR Senior Investigator and an advisor to Collateral Global. He is also an editor of the Cochrane Acute Respiratory Infections Group

DHE holds grant funding from the Canadian Institutes for Health Research and Li Ka Shing Institute of Virology relating to the development of Covid-19 vaccines as well as the Canadian Natural Science and Engineering Research Council concerning Covid-19 aerosol transmission. He is a recipient of World Health Organization and Province of Alberta funding which supports the provision of BSL3-based SARS-CoV-2 culture services to regional investigators. He also holds public and private sector contract funding relating to the development of poxvirus-based Covid-19 vaccines, SARS-CoV-2-inactivation technologies, and serum neutralization testing.

JMC holds grants from the Canadian Institutes for Health Research on acute and primary care preparedness for COVID 19 in Alberta, Canada and was the primary local Investigator for a Staphylococcus aureus vaccine study funded by Pfizer for which all funding was provided only to the University of Calgary. He is a co investigator on a WHO funded study using integrated human factors and ethnography approaches to identify and scale innovative IPC guidance implementation supports in primary care with a focus on low resource settings and using drone aerial systems to deliver medical supplies and PPE to remote First Nations communities during the COVID 19 pandemic. He also received support from the Centers for Disease Control and Prevention (CDC) to attend an Infection Control Think Tank Meeting. He is a member of the WHO Infection Prevention and Control Research and Development Expert Group for COVID 19 and the WHO Health Emergencies Programme (WHE) Ad hoc COVID 19 IPC Guidance Development Group, both of which provide multidisciplinary advice to the WHO, for which no funding is received and from which no funding recommendations are made for any WHO contracts or grants. He is also a member of the Cochrane Acute Respiratory Infections Group.

JB is a major shareholder in the Trip Database search engine (www.tripdatabase.com) as well as being an employee. In relation to this work Trip has worked with a large number of organisations over the years, none have any links with this work. The main current projects are with AXA and Collateral Global.

ECR was a member of the European Federation of Neurological Societies(EFNS) / European Academy of Neurology (EAN) Scientist Panel - Subcommittee of Infectious Diseases (2013-2017). Since 2021, she is a member of the International Parkinson and Movement Disorder Society (MDS) Multiple System Atrophy Study Group and the Mild Cognitive Impairment in Parkinson Disease Study 
medRxiv preprint doi: https://doi.org/10.1101/2021.06.30.21259750; this version posted July 5, 2021. The copyright holder for this preprint (which was not certified by peer review) is the author/funder, who has granted medRxiv a license to display the preprint in perpetuity. It is made available under a CC-BY-NC-ND 4.0 International license .

Group. She was an External Expert and sometimes Rapporteur for COST proposals (2013, 2016, 2017, 2018, 2019) for Neurology projects.

AP is Senior Research Fellow at the Centre for Evidence-Based Medicine and reports grant funding from NIHR School of Primary Care Research (NIHR SPCR ESWG project 390 and project 461), during the conduct of the study; and occasionally receives expenses for teaching Evidence-Based Medicine.

IJO, EAS have no interests to disclose.

\section{Grant information}

The review was funded by the World Health Organization: Living rapid review on the modes of transmission of SARs-CoV-2 reference WHO registration $\mathrm{N}^{\circ} 2020 / 1077093$. $\mathrm{CH}, \mathrm{AP}$ and ES also receive funding support from the NIHR SPCR Evidence Synthesis Working Group project 390.

\section{Acknowledgements}

This work was commissioned and paid for by the World Health Organization (WHO). Copyright on the original work on which this article is based belongs to WHO. The authors have been given permission to publish this article. The author(s) alone is/are responsible for the views expressed in the publication. They do not necessarily represent views, decisions, or policies of the World Health Organization.

\section{Data Availability}

All data included in the review are provided in the tables or in the supplemental files. 
medRxiv preprint doi: https://doi.org/10.1101/2021.06.30.21259750; this version posted July 5, 2021. The copyright holder for this preprint (which was not certified by peer review) is the author/funder, who has granted medRxiv a license to display the preprint in perpetuity. It is made available under a CC-BY-NC-ND 4.0 International license .

\section{References}

\section{References to included studies}

Abd EW, Eassa SM, Metwally M, Al-Hraishawi H, Omar SR. SARS-CoV-2 Transmission channels: a review of the literature. MEDICC Rev. 2020 Oct;22(4):51-69

Akhtar H, Patel C, Abuelgasim E, Harky A: COVID-19 (SARS-CoV-2) Infection in pregnancy: a systematic review. Gynecol Obstet Invest 2020;85:295-306. doi: 10.1159/000509290

Alamar I, Abu-Arja MH, Heyman T et al. A possible case of vertical transmission of Severe Acute Respiratory Syndrome Coronavirus 2 (SARS-CoV-2) in a newborn with positive placental in situ hybridization of SARS-CoV-2 RNA. J Pediatric Infect Dis Soc. 2020 Nov 10;9(5):636-639. doi: 10.1093/jpids/piaa109

AIQahtani MA, AIDajani SM. A systemic review of vertical transmission possibility in pregnant women with coronavirus disease 2019-positive status. J Family Med Prim Care. 2020 Sep 30;9(9):4521-4525. doi: 10.4103/jfmpc.jfmpc_475_20

Amaral WND, Moraes CL, Rodrigues APDS, Noll M, Arruda JT, Mendonça CR. Maternal coronavirus infections and neonates born to mothers with SARS-CoV-2: a systematic review. Healthcare (Basel). 2020 Nov 24;8(4):511. doi: 10.3390/healthcare8040511.

Anand $P$, Yadav A, Debata $P$ et al. Clinical profile, viral load, management and outcome of neonates born to COVID 19 positive mothers: a tertiary care centre experience from India. Eur J Pediatr 180, 547-559 (2021). https://doi.org/10.1007/s00431-020-03800-7

Ayed A, Embaireeg A, Benawadh A, et al. Maternal and perinatal characteristics and outcomes of pregnancies complicated with COVID-19 in Kuwait. BMC Pregnancy Childbirth. 2020 Dec 2;20(1):754. doi: 10.1186/s12884-020-03461-2

Bachani S, Arora R, Dabral A et al. Clinical profile, viral load, maternal-fetal outcomes of pregnancy with COVID-19: 4-week retrospective, tertiary care single-centre descriptive study. J Obstet Gynaecol Can. 2021 Apr;43(4):474-482. doi: 10.1016/j.jogc.2020.09.021

Bandyopadhyay T, Sharma A, Kumari P, Maria A, Choudhary R. Possible early vertical transmission of COVID-19 from an infected pregnant female to her neonate: a case report. J Trop Pediatr. 2021 Jan 29;67(1):fmaa094. doi: 10.1093/tropej/fmaa094

Barbero P, Mugüerza L, Herraiz I, et al. SARS-CoV-2 in pregnancy: characteristics and outcomes of hospitalized and non-hospitalized women due to COVID-19. J Matern Fetal Neonatal Med. $2020 \mathrm{Jul}$ 20:1-7. doi: $10.1080 / 14767058.2020 .1793320$

Bellos I, Pandita A, Panza R. Maternal and perinatal outcomes in pregnant women infected by SARS-CoV-2: A meta-analysis. Eur J Obstet Gynecol Reprod Biol. 2021 Jan;256:194-204. doi: 10.1016/j.ejogrb.2020.11.038.

Birindwa EK, Mulumeoderhwa GM, Nyakio O et al. A case study of the first pregnant woman with COVID-19 in Bukavu, eastern Democratic Republic of the Congo. Matern Health Neonatol Perinatol. 2021 Jan 20;7(1):6. doi: 10.1186/s40748-021-00127-5 
medRxiv preprint doi: https://doi.org/10.1101/2021.06.30.21259750; this version posted July 5, 2021. The copyright holder for this preprint (which was not certified by peer review) is the author/funder, who has granted medRxiv a license to display the preprint in perpetuity. It is made available under a CC-BY-NC-ND 4.0 International license .

Bordbar A, Kashaki M, Rezaei F, Jafari R. Vertical transmission of COVID-19 in a 1-day-old neonate. Travel Med Infect Dis. 2020 Nov-Dec;38:101879. doi: 10.1016/j.tmaid.2020.101879

Bwire GM, Njiro BJ, Mwakawanga DL, Sabas D, Sunguya BF. Possible vertical transmission and antibodies against SARS-CoV-2 among infants born to mothers with COVID-19: A living systematic review. J Med Virol. 2021 Mar;93(3):1361-1369. doi: 10.1002/jmv.26622

Caparros-Gonzalez RA, Pérez-Morente MA, Hueso-Montoro C, Álvarez-Serrano MA, de la Torre-Luque A. Congenital, intrapartum and postnatal maternal-fetal-neonatal SARS-CoV-2 infections: a narrative review. Nutrients. 2020 Nov 20;12(11):3570

Chaudhary S, Humayun S, Akhter H, Malik N, Humayun S, \& Nazir S. COVID-19 in pregnant women: a case series. Annals of King Edward Medical University 2020; 26(2): 336-341. Retrieved from https://www.annalskemu.org/journal/index.php/annals/article/view/3923

Chen W, Yuan P, Yang M et al. SARS-CoV-2 Entry Factors: ACE2 and TMPRSS2 are expressed in peri-implantation embryos and the maternal-fetal interface. Engineering (Beijing). 2020 Oct:6(10):1162-1169. doi: 10.1016/j.eng.2020.07.013

Chi J, Gong W \& Gao Q. Clinical characteristics and outcomes of pregnant women with COVID-19 and the risk of vertical transmission: a systematic review. Arch Gynecol Obstet 303, 337-345 (2021). https://doi.org/10.1007/s00404-020-05889-5

Cojocaru L, Crimmins S, Sundararajan S et al. An initiative to evaluate the safety of maternal bonding in patients with SARS-CoV-2 infection. J Matern Fetal Neonatal Med. 2020 Sep 30:1-7. doi: $10.1080 / 14767058.2020 .1828335$

Della Gatta AN, Rizzo R, Pilu G, Simonazzi G. Coronavirus disease 2019 during pregnancy: a systematic review of reported cases. Am J Obstet Gynecol. 2020 Jul;223(1):36-41. doi: 10.1016/j.ajog.2020.04.013

Demirjian A, Singh C, Tebruegge M et al. Probable vertical transmission of SARS-CoV-2 infection. Pediatr Infect Dis J. 2020 Sep;39(9):e257-e260. doi: 10.1097/INF.0000000000002821

Deniz M, Tezer H. Vertical transmission of SARS CoV-2: a systematic review. J Matern Fetal Neonatal Med. 2020 Jul 21:1-8. doi: 10.1080/14767058.2020.1793322.

Dhir SK, Kumar J, Meena J, Kumar P. Clinical features and outcome of SARS-CoV-2 infection in neonates: a systematic review. J Trop Pediatr. 2020 Aug 28:fmaa059. doi: 10.1093/tropej/fmaa059

Diriba K, Awulachew E \& Getu E. The effect of coronavirus infection (SARS-CoV-2, MERS-CoV, and SARS-CoV) during pregnancy and the possibility of vertical maternal-fetal transmission: a systematic review and meta-analysis. Eur J Med Res 25, 39 (2020). https://doi.org/10.1186/s40001-020-00439-w

Di Toro F, Gjoka M, Di Lorenzo G et al. Impact of COVID-19 on maternal and neonatal outcomes: a systematic review and meta-analysis. Clin Microbiol Infect. 2021 Jan;27(1):36-46. doi: 10.1016/j.cmi.2020.10.007

Dube R, Kar SS COVID-19 in pregnancy: the foetal perspective - a systematic review BMJ Paediatrics Open 2020;4:e000859. doi: 10.1136/bmjpo-2020-000859 
medRxiv preprint doi: https://doi.org/10.1101/2021.06.30.21259750; this version posted July 5, 2021. The copyright holder for this preprint (which was not certified by peer review) is the author/funder, who has granted medRxiv a license to display the preprint in perpetuity. It is made available under a CC-BY-NC-ND 4.0 International license .

Facchetti F, Bugatti M, Drera E et al. SARS-CoV2 vertical transmission with adverse effects on the newborn revealed through integrated immunohistochemical, electron microscopy and molecular analyses of Placenta. EBioMedicine. 2020 Sep;59:102951. doi: 10.1016/j.ebiom.2020.102951

Farsi Z, Taheri Derakhsh N, Bassirnia M, Ahmadi L, Shiva M, Yousefzadegan S. Coronavirus Disease-2019 infection in neonates of an infected pregnant mother with triplets. Iranian Journal of Neonatology IJN, 2020; 11(3): 120-122. doi: 10.22038/ijn.2020.49218.1856

Fenizia C, Biasin M, Cetin I. et al. Analysis of SARS-CoV-2 vertical transmission during pregnancy. Nat Commun 11, 5128 (2020). https://doi.org/10.1038/s41467-020-18933-4

Fenizia C, Biasin M, Cetin I et al. In-utero mother-to-child SARS-CoV-2 transmission: viral detection and fetal immune response. medRxiv 2020.07.09.20149591; doi: https://doi.org/10.1101/2020.07.09.20149591

Ferraiolo A, Barra F, Kratochwila C et al. Report of positive placental swabs for SARS-CoV-2 in an asymptomatic pregnant woman with COVID-19. Medicina (Kaunas). 2020 Jun 22;56(6):306. doi: 10.3390/medicina56060306

Galang RR, Chang K, Strid P et al. Severe coronavirus ilnfections in pregnancy, obstetrics \& gynecology: August 2020 - Volume 136 - Issue 2 - p 262-272 doi: 10.1097/AOG.0000000000004011

Gale C, Quigley MA, Placzek A et al. Characteristics and outcomes of neonatal SARS-CoV-2 infection in the UK: a prospective national cohort study using active surveillance. Lancet Child Adolesc Health. 2021 Feb;5(2):113-121. doi: 10.1016/S2352-4642(20)30342-4

Gao W, Deng Z, Zeng $L$ et al. A newborn with normal IgM and elevated IgG antibodies born to an asymptomatic infection mother with COVID-19. Aging (Albany NY). 2020 Sep 11;12(17):16672-16674. doi: 10.18632/aging.103346

Gao X, Wang S, Zeng W et al. Clinical and immunologic features among COVID-19-affected mother-infant pairs: antibodies to SARS-CoV-2 detected in breast milk. New Microbes New Infect. 2020 Sep;37:100752. doi: 10.1016/j.nmni.2020.100752

Gao Yj, Ye L, Zhang Js. et al. Clinical features and outcomes of pregnant women with COVID-19: a systematic review and meta-analysis. BMC Infect Dis 20, 564 (2020).

https://doi.org/10.1186/s12879-020-05274-2

Goh XL, Low YF, Ng CH, et al Incidence of SARS-CoV-2 vertical transmission: a meta-analysis Archives of Disease in Childhood - Fetal and Neonatal Edition 2021;106:112-113

Grimminck K, Santegoets LAM, Siemens FC, Fraaij PLA, Reiss IKM, Schoenmakers S. No evidence of vertical transmission of SARS-CoV-2 after induction of labour in an immune-suppressed SARS-CoV-2-positive patient. BMJ Case Rep. 2020 Jun 30;13(6):e235581. doi: 10.1136/bcr-2020-235581

Han Y, Ma H, Suo M et al. Clinical manifestation, outcomes in pregnant women with COVID-19 and the possibility of vertical transmission: a systematic review of the current data. J Perinat Med. 2020 Nov 26;48(9):912-924. doi: 10.1515/jpm-2020-0431 
medRxiv preprint doi: https://doi.org/10.1101/2021.06.30.21259750; this version posted July 5, 2021. The copyright holder for this preprint (which was not certified by peer review) is the author/funder, who has granted medRxiv a license to display the preprint in perpetuity. It is made available under a CC-BY-NC-ND 4.0 International license .

He Z, Fang Y, Zuo Q et al. Vertical transmission and kidney damage in newborns whose mothers had coronavirus disease 2019 during pregnancy. Int J Antimicrob Agents. 2021 Feb;57(2):106260. doi: 10.1016/j.ijantimicag.2020.106260

Hecht JL, Quade B, Deshpande V et al. SARS-CoV-2 can infect the placenta and is not associated with specific placental histopathology: a series of 19 placentas from COVID-19-positive mothers. Mod Pathol 33, 2092-2103 (2020). https://doi.org/10.1038/s41379-020-0639-4

Hessami K, Homayoon N, Hashemi A, Vafaei H, Kasraeian M, Asadi N. COVID-19 and maternal, fetal and neonatal mortality: a systematic review. J Matern Fetal Neonatal Med. 2020 Aug 16:1-6. doi: 10.1080/14767058.2020.1806817

Hinojosa-Velasco A, de Oca PVB, García-Sosa LE et al. A case report of newborn infant with severe COVID-19 in Mexico: Detection of SARS-CoV-2 in human breast milk and stool. Int J Infect Dis. 2020 Nov;100:21-24. doi: 10.1016/j.ijid.2020.08.055

Hsu AL, Guan M, Johannesen E et al. Placental SARS-CoV-2 in a patient with mild COVID-19 disease. medRxiv 2020.07.11.20149344; doi: https://doi.org/10.1101/2020.07.11.20149344

Hu X, Gao J, Wei Y et al. Managing preterm infants born to COVID-19 mothers: evidence from a retrospective cohort study in Wuhan, China. Neonatology. 2020;117(5):592-598. doi:

$10.1159 / 000509141$

Huntley BJF, Huntley ES, Di Mascio D, Chen T, Berghella V, Chauhan SP. Rates of maternal and perinatal mortality and vertical transmission in pregnancies complicated by Severe Acute Respiratory Syndrome Coronavirus 2 (SARS-Co-V-2) infection: a systematic review. Obstet Gynecol. 2020 Aug;136(2):303-312. doi: 10.1097/AOG.0000000000004010

Juan J, Gil MM, Rong Z, Zhang Y, Yang H, Poon LC. VP45.28: Effects of coronavirus disease 2019 (COVID-19) on maternal, perinatal and neonatal outcomes: a systematic review. Ultrasound Obstet Gynecol. 2020;56(Suppl 1):265. doi:10.1002/uog.23059

Khalil A, Kalafat E, Benlioglu C et al. SARS-CoV-2 infection in pregnancy: a systematic review and meta-analysis of clinical features and pregnancy outcomes. EClinicalMedicine. 2020 Aug;25:100446. doi: 10.1016/j.eclinm.2020.100446

Khan MA, Kumar V, Ali SR. Vertical transmission of novel coronavirus (COVID-19) from mother to newborn: experience from a maternity unit, the Indus Hospital, Karachi. J Coll Physicians Surg Pak. 2020 Oct;30(10):136. doi: 10.29271/jcpsp.2020.supp2.136

Kotlyar AM, Grechukhina O, Chen A et al. Vertical transmission of coronavirus disease 2019: a systematic review and meta-analysis. Am J Obstet Gynecol. 2021 Jan;224(1):35-53.e3. doi: 10.1016/j.ajog.2020.07.049

Kulkarni R, Rajput U, Dawre R et al. Early-onset symptomatic neonatal COVID-19 infection with high probability of vertical transmission. Infection 2021: 49; 339-343

https://doi.org/10.1007/s15010-020-01493-6

Liu W, Cheng $\mathrm{H}$, Wang $\mathrm{J}$ et al. Clinical analysis of neonates born to mothers with or without COVID-19: a retrospective analysis of 48 cases from two neonatal intensive care units in Hubei Province. Am J Perinatol. 2020 Nov;37(13):1317-1323. doi: 10.1055/s-0040-1716505 
medRxiv preprint doi: https://doi.org/10.1101/2021.06.30.21259750; this version posted July 5, 2021. The copyright holder for this preprint (which was not certified by peer review) is the author/funder, who has granted medRxiv a license to display the preprint in perpetuity. It is made available under a CC-BY-NC-ND 4.0 International license.

Luo Q, Chen L, Yao D et al. Safety of breastfeeding in mothers with SARS-CoV-2 infection medRxiv 2020.05.30.20033407; doi: https://doi.org/10.1101/2020.05.30.20033407

Lv Y, Gu B, Chen Y et al. No intrauterine vertical transmission in pregnancy with COVID-19: A case report. J Infect Chemother. 2020 Dec;26(12):1313-1315. doi: 10.1016/j.jiac.2020.07.015

Maraschini A, Corsi E, Salvatore MA, Donati S, ItOSS COVID-19 working group. Coronavirus and birth in Italy: results of a national population-based cohort study. medRxiv 2020.06.11.20128652; doi: https://doi.org/10.1101/2020.06.11.20128652

Marín Gabriel MA, Reyne Vergeli M, Caserío Carbonero S, et al incl. Neo-COVID-19 Research Group. Maternal, perinatal and neonatal outcomes with COVID-19: a multicenter study of 242 pregnancies and their 248 infant newborns during their first month of life. Pediatr Infect Dis J. 2020 Dec;39(12):e393-e397. doi: 10.1097/INF.0000000000002902

Masmejan S, Pomar L, Favre G et al. Vertical transmission and materno-fetal outcomes in 13 patients with coronavirus disease 2019. Clin Microbiol Infect. 2020 Nov;26(11):1585-1587. doi:

10.1016/j.cmi.2020.06.035

Melo GC, Araújo KCGM. COVID-19 infection in pregnant women, preterm delivery, birth weight, and vertical transmission: a systematic review and meta-analysis. Cad Saude Publica.

2020;36(7):e00087320. doi: 10.1590/0102-311x00087320

Mohakud NK, Yerru H Jr, Rajguru M, Naik SS. An assumed vertical transmission of SARS-CoV-2 during pregnancy: a case report and review of literature. Cureus. 2020 Sep 26;12(9):e10659. doi: 10.7759/cureus. 10659

Moreno SC, To J, Chun H, Ngai IM. Vertical Transmission of COVID-19 to the Neonate. Infect Dis Obstet Gynecol. 2020 Nov 12;2020:8460672. doi: 10.1155/2020/8460672

Nayak AH, Kapote DS, Fonseca M et al. Impact of the coronavirus infection in pregnancy: a preliminary study of 141 patients. J Obstet Gynecol India 70, 256-261 (2020).

https://doi.org/10.1007/s13224-020-01335-3

Novoa RH, Quintana W, Llancarí P, Urbina-Quispe K, Guevara-Ríos E, Ventura W. Maternal clinical characteristics and perinatal outcomes among pregnant women with coronavirus disease 2019. A systematic review. Travel Med Infect Dis. 2021 Jan-Feb;39:101919. doi: 10.1016/j.tmaid.2020.101919

Ogamba I, Kliss A, Rainville $\mathrm{N}$ et al. Initial review of pregnancy and neonatal outcomes of pregnant women with COVID-19 infection. J Perinat Med. 2020 Nov 3;49(3):263-268. doi: 10.1515/jpm-2020-0446

Olivini N, Calò Carducci FI, Santilli V et al. A neonatal cluster of novel coronavirus disease 2019: clinical management and considerations. Ital J Pediatr 46, 180 (2020).

https://doi.org/10.1186/s13052-020-00947-9

Oncel MY, Akın IM, Kanburoglu MK et al. A multicenter study on epidemiological and clinical characteristics of 125 newborns born to women infected with COVID-19 by Turkish Neonatal Society. Eur J Pediatr 180, 733-742 (2021). https://doi.org/10.1007/s00431-020-03767-5 
medRxiv preprint doi: https://doi.org/10.1101/2021.06.30.21259750; this version posted July 5, 2021. The copyright holder for this preprint (which was not certified by peer review) is the author/funder, who has granted medRxiv a license to display the preprint in perpetuity. It is made available under a CC-BY-NC-ND 4.0 International license .

Palalioglu RM, Mahammadaliyeva A, Erbiyik HI, Muhcu M. COVID-19 in third trimester may not be as scary as you think, it can be innocent: Evaluating vertical transmission from a COVID-19 positive asymptomatic pregnant woman with early membrane rupture. J Obstet Gynaecol Res. 2021;47(2):838-842. doi:10.1111/jog.14584

Parsa Y, Shokri N, Jahedbozorgan T, Naeiji Z, Zadehmodares S, Moridi A. Possible vertical transmission of COVID-19 to the newborn; a case report. Arch Acad Emerg Med. 2020;9(1):e5. Published 2020 Nov 14. doi:10.22037/aaem.v9i1.923

Pereira A, Cruz-Melguizo S, Adrien M et al. Breastfeeding mothers with COVID-19 infection: a case series. Int Breastfeed J 15, 69 (2020). https://doi.org/10.1186/s13006-020-00314-8

Pessoa FS, Vale MSD, Marques PF, Figueira SDS, Salgado IADSC, Mochel RSWC. Probable vertical transmission identified within six hours of life. Rev Assoc Med Bras (1992). 2020 Dec;66(12):1621-1624. doi: 10.1590/1806-9282.66.12.1621. PMID: 33331566

Pettirosso E, Giles M, Cole S, Rees M. COVID-19 and pregnancy: A review of clinical characteristics, obstetric outcomes and vertical transmission. Aust N Z J Obstet Gynaecol. 2020 Oct;60(5):640-659. doi: 10.1111/ajo.13204

Pissarra S, Rosário M, Moucho M, Soares H. Perinatal management of SARS-CoV-2 infection in a level III University Hospital. J Matern Fetal Neonatal Med. 2020 Jul 23:1-4. doi: 10.1080/14767058.2020.1786526

Popofsky S, Noor A, Leavens-Maurer J et al. Impact of maternal Severe Acute Respiratory Syndrome Coronavirus 2 Detection on Breastfeeding Due to Infant Separation at Birth. J Pediatr. 2020 Aug 10;226:64-70. doi: 10.1016/j.jpeds.2020.08.004

Pulinx B, Kieffer D, Michiels I. et al. Vertical transmission of SARS-CoV-2 infection and preterm birth. Eur J Clin Microbiol Infect Dis. 2020; 39: 2441-2445. https://doi.org/10.1007/s10096-020-03964-y

Raschetti R, Vivanti AJ, Vauloup-Fellous C et al. Synthesis and systematic review of reported neonatal SARS-CoV-2 infections. Nat Commun 2020; 11: 5164.

https://doi.org/10.1038/s41467-020-18982-9

Rebello CM, Fascina LP, Annicchino G et al. Vertical transmission of SARS-CoV-2 from infected pregnant mother to the neonate detected by cord blood real-time polymerase chain reaction (RT-PCR). Pediatr Res 2020. https://doi.org/10.1038/s41390-020-01193-9

Rivera-Hernandez P, Nair J, Islam S, Davidson L, Chang A, Elberson V. Coronavirus disease 2019 in a premature infant: vertical transmission and antibody response or lack thereof. AJP Rep. 2020 Jul;10(3):e224-e227. doi: 10.1055/s-0040-1715176

Rodrigues C, Baía I, Domingues R, Barros H. Pregnancy and breastfeeding during COVID-19 pandemic: a systematic review of published pregnancy cases. Front Public Health. $2020 \mathrm{Nov}$ 23;8:558144. doi: 10.3389/fpubh.2020.558144

Rubio Lorente AM, Pola Guillén M, López Jimenez N, Moreno-Cid Garcia-Suelto M, Rodriguez Rodriguez E, Pascual Pedreño A. Study of amniotic fluid in pregnant women infected with SARS-CoV-2 in first and second trimester. Is there evidence of vertical transmission? J Matern Fetal Neonatal Med. 2020 Aug 30:1-3. doi: 10.1080/14767058.2020.1811669 
medRxiv preprint doi: https://doi.org/10.1101/2021.06.30.21259750; this version posted July 5, 2021. The copyright holder for this preprint (which was not certified by peer review) is the author/funder, who has granted medRxiv a license to display the preprint in perpetuity. It is made available under a CC-BY-NC-ND 4.0 International license .

Sajjan GR \& Sajjan KR. A case report on vertical transmission of Covid-19 presenting as gangrene of lower limb in neonate. Int J Clinical Obstetrics and Gynaecology 2020; 4(6): 65-66.

Sampieri CL, Montero H. Revisión de nuevas evidencias acerca de la posible transmisión vertical de la COVID-19 [Review of new evidence about the possible vertical transmission of coronavirus disease-2019]. Gac Sanit. 2020 Jun 20:S0213-9111(20)30137-0. Spanish. doi: 10.1016/j.gaceta.2020.06.005

Schwartz DA, Mohagheghi P, Beigi B, Zafaranloo N, Moshfegh F, Yazdani A. Spectrum of neonatal COVID-19 in Iran: 19 infants with SARS-CoV-2 perinatal infections with varying test results, clinical findings and outcomes. J Matern Fetal Neonatal Med. 2020 Aug 12:1-10. doi:

$10.1080 / 14767058.2020 .1797672$

Shende P, Gaikwad P, Gandhewar M et al. Persistence of SARS-CoV-2 in the first trimester placenta leading to vertical transmission and fetal demise from an asymptomatic mother.

medRxiv 2020.08.18.20177121; doi: https://doi.org/10.1101/2020.08.18.20177121

Sheth S, Shah N, Bhandari V. Outcomes in COVID-19 positive neonates and possibility of viral vertical transmission: a narrative review. Am J Perinatol. 2020 Oct;37(12):1208-1216. doi:

10.1055/s-0040-1714719

Shrestha R, Basnet S, \& Shrestha L. Foetal and Neonatal Outcome in Pregnant Women with COVID-19. Journal of Nepal Paediatric Society 2020 40(3): 143-156.

https://doi.org/10.3126/jnps.v40i3.29844

Singh MV, Shrivastava A, Maurya M, Tripathi A, Sachan R, Siddiqui SA. Vertical transmission of SARS-CoV-2 from an asymptomatic pregnant woman in India. J Trop Pediatr. 2020 Sep 25:fmaa048. doi: 10.1093/tropej/fmaa048

Sisman J, Jaleel MA, Moreno W et al. Intrauterine transmission of SARS-COV-2 infection in a preterm infant. Pediatr Infect Dis J. 2020 Sep;39(9):e265-e267. doi: 10.1097/INF.0000000000002815

Smithgall MC, Liu-Jarin X, Hamele-Bena D et al. Third-trimester placentas of severe acute respiratory syndrome coronavirus 2 (SARS-CoV-2)-positive women: histomorphology, including viral immunohistochemistry and in-situ hybridization. Histopathology. 2020 Dec;77(6):994-999. doi: 10.1111/his.14215

Stonoga ES, de Almeida Lanzoni L, Rebutini P et al. Intrauterine transmission of SARS-CoV-2. Emerg Infect Dis. 2021;27(2):638-641. https://doi.org/10.3201/eid2702.203824

Tang F, Luo W, Wang Xiaowen et al, An observational study of intrauterine vertical transmission of SARS-CoV-2 in 20 neonates (5/30/2020). [preprint] http://dx.doi.org/10.2139/ssrn.3618210

Tang JY, Song WQ, Xu H, Wang N. No evidence for vertical transmission of SARS-CoV-2 in two neonates with mothers infected in the second trimester. Infect Dis (Lond). 2020

Nov-Dec;52(12):913-916. doi: 10.1080/23744235.2020.1798499

Thomas P, Alexander PE, Ahmed U et al. Vertical transmission risk of SARS-CoV-2 infection in the third trimester: a systematic scoping review. J Matern Fetal Neonatal Med. 2020 Jul 1:1-8. doi: 10.1080/14767058.2020.1786055 
medRxiv preprint doi: https://doi.org/10.1101/2021.06.30.21259750; this version posted July 5, 2021. The copyright holder for this preprint (which was not certified by peer review) is the author/funder, who has granted medRxiv a license to display the preprint in perpetuity. It is made available under a CC-BY-NC-ND 4.0 International license .

Trippella G, Ciarcià M, Ferrari M et al. COVID-19 in pregnant women and neonates: a systematic review of the literature with quality assessment of the studies. Pathogens. 2020 Jun 18;9(6):485. doi: 10.3390/pathogens 9060485

Turan O, Hakim A, Dashraath P, Jeslyn WJL, Wright A, Abdul-Kadir R. Clinical characteristics, prognostic factors, and maternal and neonatal outcomes of SARS-CoV-2 infection among hospitalized pregnant women: A systematic review. Int J Gynaecol Obstet. 2020 Oct;151(1):7-16. doi: 10.1002/ijgo.13329

Vendola N, Stampini V, Amadori R, Gerbino M, Curatolo A, Surico D. Vertical transmission of antibodies in infants born from mothers with positive serology to COVID-19 pneumonia. Eur J Obstet Gynecol Reprod Biol. 2020 Oct;253:331-332. doi: 10.1016/j.ejogrb.2020.08.023

Viñuela MC, De León-Luis JA, Alonso R, et al incl. Obstetrics and Gynecology and Microbiology-ID COVID 19 Study Group. SARS-CoV-2 screening of asymptomatic women admitted for delivery must be performed with a combination of microbiological techniques: an observational study. Rev Esp Quimioter. 2020 Dec;33(6):415-421. doi: 10.37201/req/088.2020

Vivanti AJ, Vauloup-Fellous C, Prevot S et al. Transplacental transmission of SARS-CoV-2 infection. Nat Commun 2020; 11: 3572. https://doi.org/10.1038/s41467-020-17436-6

Von Kohorn I, Stein SR, Shikani BT et al. In utero Severe Acute Respiratory Syndrome Coronavirus 2 infection. J Pediatric Infect Dis Soc. 2020 Dec 31;9(6):769-771. doi: 10.1093/jpids/piaa127

Vouga M, Favre G, Martinez Perez O et al. Maternal and obstetrical outcomes in a cohort of pregnant women tested for SARS-CoV-2: interim results of the COVI-Preg International Registry. [preprint] http://dx.doi.org/10.2139/ssrn.3684424

Walker GJ, Clifford V, Bansal N et al. SARS-CoV-2 in human milk is inactivated by Holder pasteurization but not cold storage. [preprint] medRxiv 2020.06.18.20134395; doi:

https://doi.org/10.1101/2020.06.18.20134395

Walker KF, O'Donoghue K, Grace N et al. Maternal transmission of SARS-COV-2 to the neonate, and possible routes for such transmission: a systematic review and critical analysis. BJOG. 2020 Oct;127(11):1324-1336. doi: 10.1111/1471-0528.16362

Woodworth KR, Olsen EO, Neelam V, et al. Birth and infant outcomes following laboratory-confirmed SARS-CoV-2 infection in pregnancy - SET-NET, 16 Jurisdictions, March 29-October 14, 2020.

MMWR Morb Mortal Wkly Rep 2020;69:1635-1640. DOI: http://dx.doi.org/10.15585/mmwr.mm6944e2

Yang R, Mei H, Zheng T et al. Pregnant women with COVID-19 and risk of adverse birth outcomes and maternal-fetal vertical transmission: a population-based cohort study in Wuhan, China. BMC Med 2020; 18: 330. https://doi.org/10.1186/s12916-020-01798-1

Yoon SH, Kang JM, Ahn JG. Clinical outcomes of 201 neonates born to mothers with COVID-19: a systematic review. Eur Rev Med Pharmacol Sci. 2020 Jul;24(14):7804-7815. doi:

10.26355/eurrev_202007_22285 
medRxiv preprint doi: https://doi.org/10.1101/2021.06.30.21259750; this version posted July 5, 2021. The copyright holder for this preprint (which was not certified by peer review) is the author/funder, who has granted medRxiv a license to display the preprint in perpetuity. It is made available under a CC-BY-NC-ND 4.0 International license .

Zaigham M, Holmberg A, Karlberg ML et al. Intrauterine vertical SARS-CoV-2 infection: a case confirming transplacental transmission followed by divergence of the viral genome. BJOG. 2021 Feb 27:10.1111/1471-0528.16682. doi: 10.1111/1471-0528.16682

Zhang L, Dong L, Ming L et al. Severe acute respiratory syndrome coronavirus 2(SARS-CoV-2) infection during late pregnancy: a report of 18 patients from Wuhan, China. BMC Pregnancy Childbirth 2020; 20: 394. https://doi.org/10.1186/s12884-020-03026-3

Zhang P, Salafia C, Heyman T, Salafia C, Lederman S, Dygulska B. Detection of severe acute respiratory syndrome coronavirus 2 in placentas with pathology and vertical transmission. Am J Obstet Gynecol MFM. 2020 Nov;2(4):100197. doi: 10.1016/j.ajogmf.2020.100197

Zheng T, Guo J, He W et al. Coronavirus disease 2019 (COVID-19) in pregnancy: 2 case reports on maternal and neonatal outcomes in Yichang city, Hubei Province, China, Medicine: July 17, 2020 Volume 99 - Issue 29 - p e21334 doi: 10.1097/MD.0000000000021334

\section{Other references}

1. Schwartz DA, Graham AL. Potential Maternal and Infant Outcomes from Coronavirus 2019-nCoV Infecting Pregnant Women: Lessons from SARS, MERS, and Other Human Coronavirus Infections. Viruses. 2020;12(2):194. Published 2020 Feb 10. doi:10.3390/v12020194

2. WHO Scientific Brief 2021. Definition and categorization of the timing of mother-to-child transmission of SARS-CoV-2. WHO reference number WHO/2019-nCoV/mother-to-child_transmission/2021.1

3. Akhtar H, Patel C, Abuelgasim E, Harky A: COVID-19 (SARS-CoV-2) Infection in Pregnancy: A Systematic Review. Gynecol Obstet Invest 2020;85:295-306. doi: 10.1159/000509290

4. Thomas $\mathrm{P}$, Alexander PE, Ahmed $\mathrm{U}$ et al. Vertical transmission risk of SARS-CoV-2 infection in the third trimester: a systematic scoping review. J Matern Fetal Neonatal Med. $2020 \mathrm{Jul}$ 1:1-8. doi: 10.1080/14767058.2020.1786055.

5. Galang RR, Chang K, Strid P et al. Severe Coronavirus Infections in Pregnancy, Obstetrics \& Gynecology: August 2020 - Volume 136 - Issue 2 - p 262-272 doi: 10.1097/AOG.0000000000004011

6. Bwire GM, Njiro BJ, Mwakawanga DL, Sabas D, Sunguya BF. Possible vertical transmission and antibodies against SARS-CoV-2 among infants born to mothers with COVID-19: A living systematic review. J Med Virol. 2021 Mar;93(3):1361-1369. doi: 10.1002/jmv.26622

7. Blumberg DA, Underwood MA, Hedriana HL, Lakshminrusimha S. Vertical Transmission of SARS-CoV-2: What is the Optimal Definition?. Am J Perinatol. 2020;37(8):769-772. doi:10.1055/s-0040-1712457

8. Knight M, Bunch K, Vousden N, et al. Characteristics and outcomes of pregnant women admitted to hospital with confirmed SARS-CoV-2 infection in UK: national population based cohort study. BMJ. 2020;369:m2107. Published 2020 Jun 8. doi:10.1136/bmj.m2107

9. Whiting PF, Rutjes AW, Westwood ME et al incl. QUADAS-2 Group. QUADAS-2: a revised tool for the quality assessment of diagnostic accuracy studies. Ann Intern Med. 2011 Oct 18;155(8):529-36. doi: 10.7326/0003-4819-155-8-201110180-00009.

10. Marín Gabriel MA, Cuadrado I, Álvarez Fernández B et al incl. Neo-COVID-19 Research Group. Multicentre Spanish study found no incidences of viral transmission in infants born to mothers with COVID-19. Acta Paediatr. 2020 Nov;109(11):2302-2308. doi: 10.1111/apa.15474. 
medRxiv preprint doi: https://doi.org/10.1101/2021.06.30.21259750; this version posted July 5, 2021. The copyright holder for this preprint (which was not certified by peer review) is the author/funder, who has granted medRxiv a license to display the preprint in perpetuity. It is made available under a CC-BY-NC-ND 4.0 International license.

11. Bragg $F$, Cromwell D A, Edozien $L C$ et al. Variation in rates of caesarean section among English NHS trusts after accounting for maternal and clinical risk: cross sectional study BMJ 2010; 341 :c5065 doi:10.1136/bmj.c5065.

12. Endalamaw A, Demsie A, Eshetie S, Habtewold TD. A systematic review and meta-analysis of vertical transmission route of HIV in Ethiopia. BMC Infect Dis. 2018 Jun 22;18(1):283. doi: 10.1186/s12879-018-3189-3.

13. Ferreira FCPADM, da Silva ASV, Recht J, Guaraldo L, Moreira MEL, de Siqueira AM, Gerardin P, Brasil P. Vertical transmission of chikungunya virus: A systematic review. PLoS One. 2021 Apr 23;16(4):e0249166. doi: 10.1371/journal.pone.0249166.

14. Margioula-Siarkou C, Kalogiannidis I, Petousis S, et al. Cytomegalovirus, Toxoplasma gondii and Rubella vertical transmission rates according to mid-trimester amniocentesis: a retrospective study. Int J Prev Med. 2015;6:32. Published 2015 Apr 8. doi:10.4103/2008-7802.154774.

15. Jefferson T, Heneghan C, Spencer $E$ et al. A hierarchical framework for assessing transmission causality of respiratory viruses. Preprints 2021, 2021040633. doi: 10.20944/preprints202104.0633.v1. 
medRxiv preprint doi: https://doi.org/10.1101/2021.06.30.21259750; this version posted July 5, 2021. The copyright holder for this preprint (which was not certified by peer review) is the author/funder, who has granted medRxiv a license to display the preprint in perpetuity. It is made available under a CC-BY-NC-ND 4.0 International license.

\section{Tables and figures}

Figure 1. PRISMA flow diagram

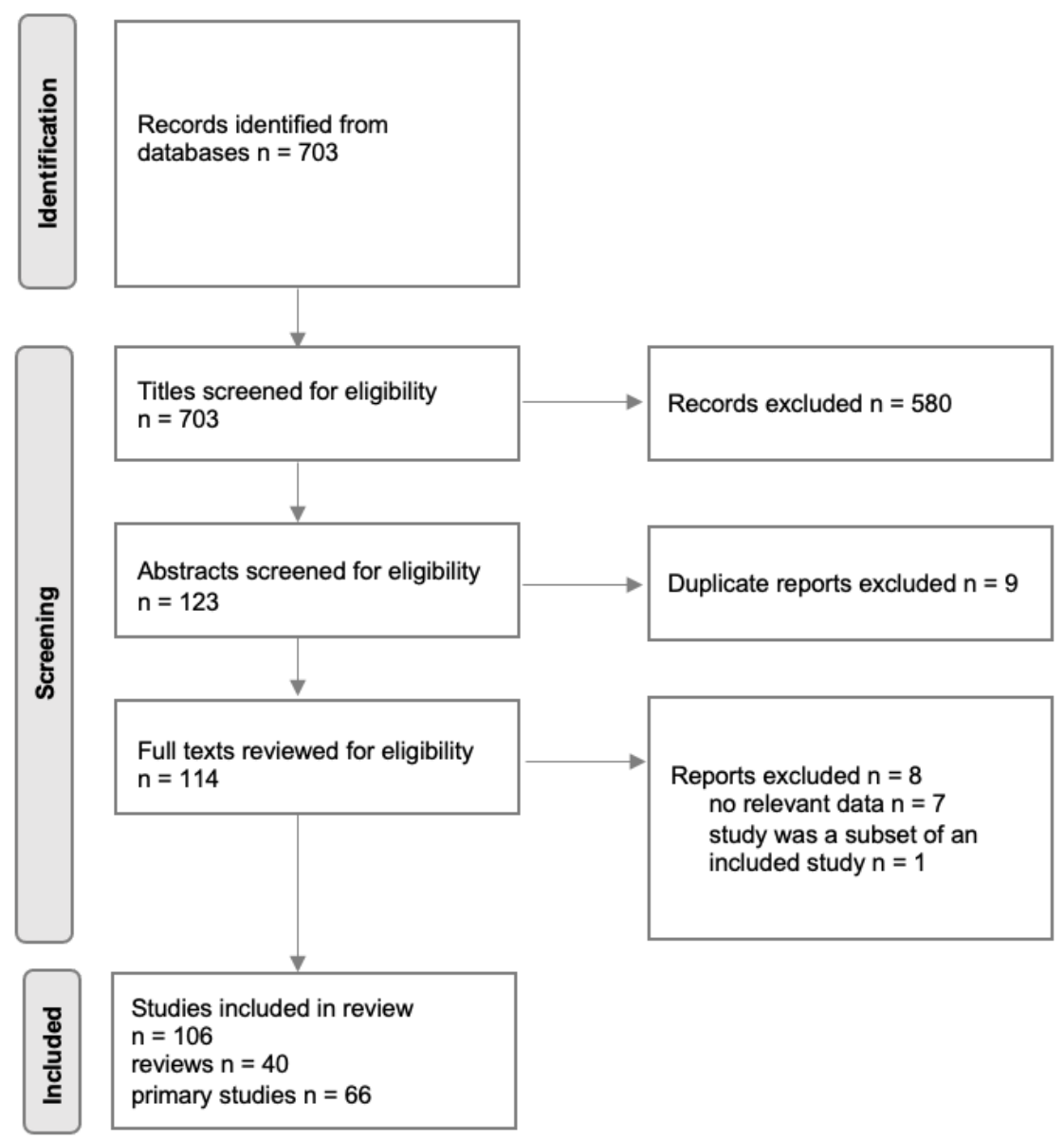


medRxiv preprint doi: https://doi.org/10.1101/2021.06.30.21259750; this version posted July 5, 2021. The copyright holder for this preprint (which was not certified by peer review) is the author/funder, who has granted medRxiv a license to display the preprint in perpetuity. It is made available under a CC-BY-NC-ND 4.0 International license.

Figure 2. Percentage neonates positive for SARS-CoV-2 within $24 \mathrm{~h}$.

Percentage neonates positive SARs-CoV-2 RNA within 24h of birth, ( $\mathrm{n}=32$ studies, 2391 neonates )

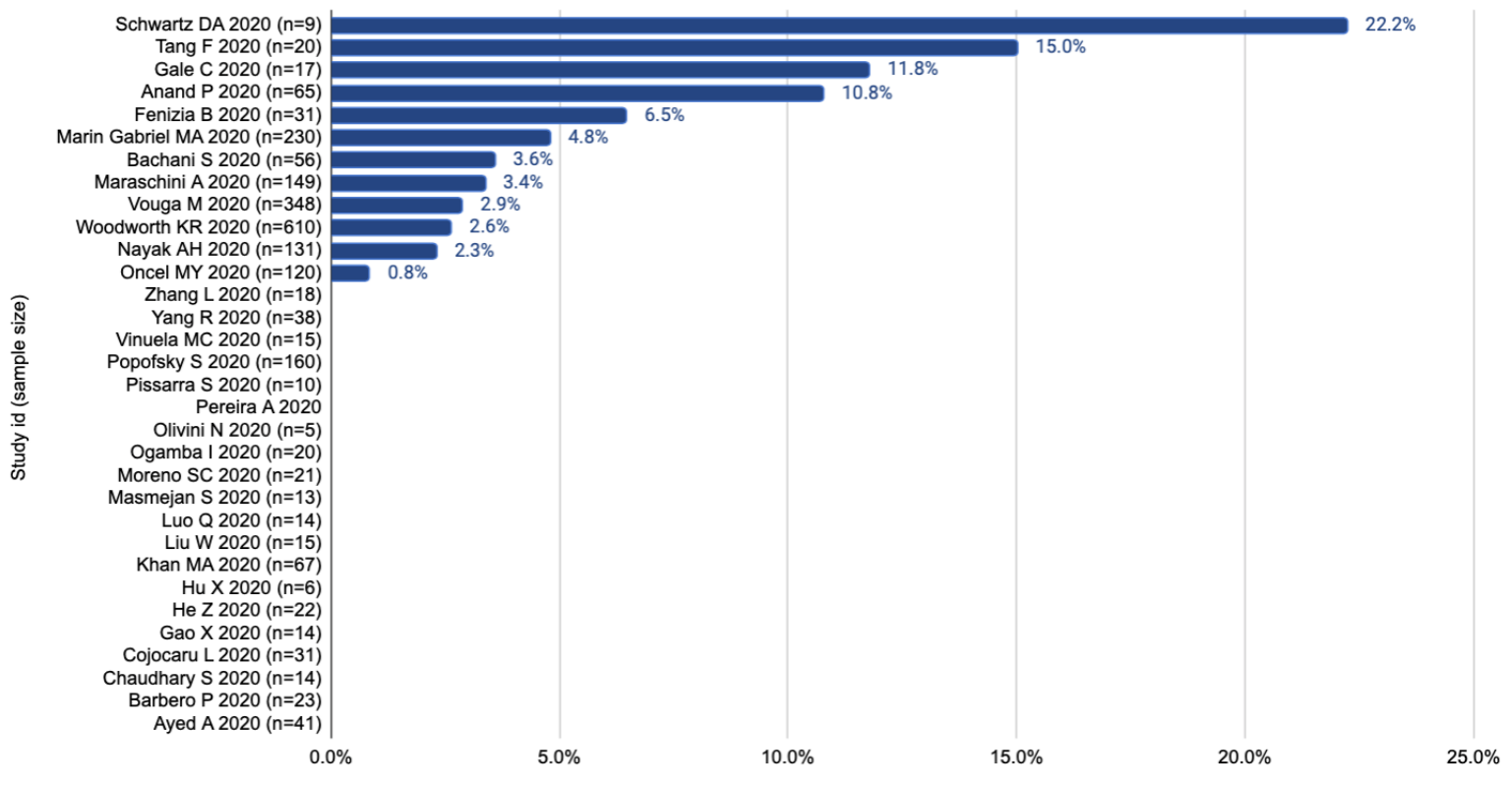

Percentage neonates positive for SARs-CoV-2 RNA 
medRxiv preprint doi: https://doi.org/10.1101/2021.06.30.21259750; this version posted July 5, 2021. The copyright holder for this preprint (which was not certified by peer review) is the author/funder, who has granted medRxiv a license to display the preprint in perpetuity. It is made available under a CC-BY-NC-ND 4.0 International license.

Table 2. Quality assessment of included primary studies.

\begin{tabular}{|c|c|c|c|c|c|}
\hline Study & $\begin{array}{l}\text { Description of } \\
\text { methods and } \\
\text { sufficient detail to } \\
\text { replicate }\end{array}$ & $\begin{array}{l}\text { Sample sources } \\
\text { clear }\end{array}$ & \begin{tabular}{|l} 
Analysis \& \\
reporting \\
appropriate
\end{tabular} & $\begin{array}{l}\text { Is bias } \\
\text { addressed }\end{array}$ & Applicability \\
\hline Anand P 2020 & Yes & Yes & Yes & Yes & Yes \\
\hline Ayed A 2020 & Yes & Yes & Yes & Unclear & Yes \\
\hline Bachani S 2020 & Yes & Yes & Yes & Unclear & Yes \\
\hline Barbero P 2020 & Yes & Yes & Yes & Unclear & Yes \\
\hline Chaudhary S 2020 & Yes & Unclear & Yes & No & Yes \\
\hline Cojocaru L 2020 & Yes & Yes & Yes & No & Yes \\
\hline Fenizia B 2020 & Yes & Yes & Yes & No & Yes \\
\hline Gale C 2020 & Yes & Yes & Unclear & Unclear & Unclear \\
\hline Gao X 2020 & Unclear & Yes & Yes & No & Unclear \\
\hline He Z 2020 & Yes & Yes & Yes & No & Yes \\
\hline $\mathrm{Hu} \times 2020$ & Yes & Yes & Yes & No & Yes \\
\hline Khan MA 2020 & Yes & Unclear & Yes & No & Yes \\
\hline Liu W 2020 & Yes & Yes & Yes & No & Yes \\
\hline Luo Q 2020 & Yes & Yes & Yes & No & Yes \\
\hline Maraschini A 2020 & Unclear & Yes & Yes & Unclear & Yes \\
\hline $\begin{array}{l}\text { Marin Gabriel MA } \\
2020\end{array}$ & Yes & Yes & Yes & No & Yes \\
\hline Masmejan S 2020 & Yes & Yes & Yes & No & Yes \\
\hline Moreno SC 2020 & Yes & Yes & Yes & No & Yes \\
\hline
\end{tabular}


medRxiv preprint doi: https://doi.org/10.1101/2021.06.30.21259750; this version posted July 5, 2021. The copyright holder for this preprint (which was not certified by peer review) is the author/funder, who has granted medRxiv a license to display the preprint in perpetuity. It is made available under a CC-BY-NC-ND 4.0 International license .

\begin{tabular}{|c|c|c|c|c|c|}
\hline Nayak AH 2020 & Yes & Unclear & Yes & No & Unclear \\
\hline Ogamba I 2020 & Yes & Yes & Yes & No & Yes \\
\hline Olivini N 2020 & Unclear & Yes & Yes & No & Unclear \\
\hline Oncel MY 2020 & Yes & Yes & Yes & No & Yes \\
\hline Pereira A 2020 & Yes & Unclear & Yes & No & Yes \\
\hline Pissarra S 2020 & Yes & Yes & Yes & No & Yes \\
\hline Popofsky S 2020 & Yes & Yes & Yes & No & Unclear \\
\hline Smithgall MC 2020 & Yes & Yes & Yes & No & Yes \\
\hline Schwartz DA 2020 & Unclear & Yes & Yes & No & Unclear \\
\hline Tang F 2020 & Yes & Unclear & Yes & No & Yes \\
\hline Vinuela MC 2020 & Yes & Unclear & Yes & No & Yes \\
\hline Vouga M 2020 & Yes & Yes & Yes & Yes & Yes \\
\hline $\begin{array}{l}\text { Woodworth KR } \\
2020\end{array}$ & Unclear & No & Unclear & No & Unclear \\
\hline Yang R 2020 & Yes & Yes & Yes & No & Yes \\
\hline Zhang L 2020 & Yes & Yes & Yes & No & Yes \\
\hline Zhang P 2020 & Unclear & Yes & Yes & No & Unclear \\
\hline
\end{tabular}


medRxiv preprint doi: https://doi.org/10.1101/2021.06.30.21259750; this version posted July 5, 2021. The copyright holder for this preprint (which was not certified by peer review) is the author/funder, who has granted medRxiv a license to display the preprint in perpetuity. It is made available under a CC-BY-NC-ND 4.0 International license.

Table 3. Main findings of included cohort and case series studies.

\begin{tabular}{|c|c|c|c|c|c|c|c|c|}
\hline Study & Ppts (n) & $\begin{array}{l}\text { No. of } \\
\text { women } \\
\text { diagnosed } \\
\text { with } \\
\text { COVID-19* }\end{array}$ & $\begin{array}{l}\text { No. of } \\
\text { births }\end{array}$ & \begin{tabular}{|c|} 
No.of \\
positive \\
neonates \\
/no. of \\
neonates \\
tested from \\
women \\
with \\
covID-19 \\
diagnosis)
\end{tabular} & \begin{tabular}{|l} 
No. of \\
positive \\
neonates \\
(RT-PCR) \\
at birth \\
(testing \\
positive \\
within \\
$24 \mathrm{~h}$ of \\
birth)
\end{tabular} & $\begin{array}{l}\text { Total } \\
\text { number of } \\
\text { neonates } \\
\text { from } \\
\text { women with } \\
\text { COVID-19 } \\
\text { diagnosis }\end{array}$ & $\begin{array}{l}\% \\
\text { neonates } \\
\text { positive } \\
\text { for SARs- } \\
\text { CoV-2 } \\
\text { RNA }\end{array}$ & $\begin{array}{l}\text { Clinical outcomes for } \\
\text { neonates testing } \\
\text { positive }\end{array}$ \\
\hline Ayed A 2020 & 185 & 185 & 41 & $2 / 41$ & 0 & 41 & $0.0 \%$ & $\begin{array}{l}1 \text { asymptomatic, } 1 \\
\text { developed tachypnoea } \\
\text { required humidified high } \\
\text { flow nasal cannula for } 5 \\
\text { days. No deaths }\end{array}$ \\
\hline Barbero P 2020 & 91 & 91 & 23 & $0 / 23$ & 0 & 23 & $0.0 \%$ & $\mathrm{n} / \mathrm{a}$ \\
\hline $\begin{array}{l}\text { Chaudhary S } \\
2020\end{array}$ & 26 & 26 & 14 & $0 / 14$ & 0 & 14 & $0.0 \%$ & $\mathrm{n} / \mathrm{a}$ \\
\hline Cojocaru L 2020 & 1989 & 86 & $\begin{array}{l}34 ; 31 \\
\text { tested }\end{array}$ & $0 / 31$ & 0 & 31 & $0.0 \%$ & $\mathrm{n} / \mathrm{a}$ \\
\hline Gao X 2020 & 14 & 14 & 14 & $0 / 14$ & 0 & 14 & $0.0 \%$ & $\mathrm{n} / \mathrm{a}$ \\
\hline He Z 2020 & 22 & 22 & 22 & $0 / 22$ & 0 & 22 & $0.0 \%$ & $\mathrm{n} / \mathrm{a}$ \\
\hline Hu X 2020 & 6 & 6 & 6 & $0 / 6$ & 0 & 6 & $0.0 \%$ & $\mathrm{n} / \mathrm{a}$ \\
\hline Khan MA 2020 & 66 & 66 & 67 & $0 / 67$ & 0 & 67 & $0.0 \%$ & $\mathrm{n} / \mathrm{a}$ \\
\hline Liu W 2020 & 48 & 15 & 48 & $0 / 15$ & 0 & 15 & $0.0 \%$ & $\mathrm{n} / \mathrm{a}$ \\
\hline Luo Q 2020 & 23 & 14 & 23 & $0 / 14$ & 0 & 14 & $0.0 \%$ & $\mathrm{n} / \mathrm{a}$ \\
\hline $\begin{array}{l}\text { Masmejan S } \\
2020(n=13)\end{array}$ & 13 & 13 & 13 & $0 / 13$ & 0 & 13 & $0.0 \%$ & $n / a$ \\
\hline $\begin{array}{l}\text { Moreno SC } \\
2020\end{array}$ & 19 & 19 & 21 & $0 / 21$ & 0 & 21 & $0.0 \%$ & $\mathrm{n} / \mathrm{a}$ \\
\hline Ogamba I 2020 & 40 & 40 & $\begin{array}{l}25 ; 20 \\
\text { tested }\end{array}$ & $0 / 20$ & 0 & 20 & $0.0 \%$ & $n / a$ \\
\hline Olivini N 2020 & 5 & 5 & 5 & $4 / 5$ & 0 & 5 & $0.0 \%$ & $\begin{array}{l}\text { Two of the positive } \\
\text { neonates developed } \\
\text { symptoms possibly } \\
\text { related to SARS -CoV-2, } \\
\text { no serious illness, no } \\
\text { deaths. }\end{array}$ \\
\hline Pereira A 2020 & 22 & 22 & 22 & $0 / 22$ & 0 & 22 & $0.0 \%$ & $n / a$ \\
\hline Pissarra S 2020 & 10 & 10 & 10 & $0 / 10$ & 0 & 10 & $0.0 \%$ & $n / a$ \\
\hline
\end{tabular}


medRxiv preprint doi: https://doi.org/10.1101/2021.06.30.21259750; this version posted July 5, 2021. The copyright holder for this preprint (which was not certified by peer review) is the author/funder, who has granted medRxiv a license to display the preprint in perpetuity. It is made available under a CC-BY-NC-ND 4.0 International license.

\begin{tabular}{|c|c|c|c|c|c|c|c|c|}
\hline $\begin{array}{l}\text { Popofsky S } \\
2020\end{array}$ & 160 & 160 & 160 & $1 / 160$ & 0 & 160 & $0.0 \%$ & $\begin{array}{l}\text { In the cohort, among the } \\
15 \text { symptomatic } \\
\text { neonates, } 4 \text { had fever, } \\
11 \text { had respiratory } \\
\text { distress, } 4 \text { had feeding } \\
\text { intolerance, } 1 \text { had } \\
\text { rhinorrhea, and } 7 \text { had } \\
\text { hypothermia. Only one } \\
\text { tested positive for } \\
\text { SARS-CoV-2 }\end{array}$ \\
\hline $\begin{array}{l}\text { Vinuela MC } \\
2020\end{array}$ & 100 & 15 & 100 & $0 / 15$ & 0 & 15 & $0.0 \%$ & $\mathrm{n} / \mathrm{a}$ \\
\hline Yang R 2020 & 11078 & 65 & $\begin{array}{c}11078 \\
38 \\
\text { neonates } \\
\text { from } 65 \\
\text { positive } \\
\text { women } \\
\text { tested }\end{array}$ & $0 / 38$ & 0 & 38 & $0.0 \%$ & $\mathrm{n} / \mathrm{a}$ \\
\hline Zhang L 2020 & 18 & 18 & 18 & $0 / 18$ & 0 & 18 & $0.0 \%$ & $\mathrm{n} / \mathrm{a}$ \\
\hline Oncel MY 2020 & 125 & 125 & $\begin{array}{c}125 ; 120 \\
\text { tested }\end{array}$ & $4 / 120$ & 1 & 120 & $0.8 \%$ & $\begin{array}{l}1 \text { asymptomatic, } 3 \\
\text { required mechanical } \\
\text { ventilation or nasal } \\
\text { CPAP; however unclear } \\
\text { whether these } \\
\text { requirements were due } \\
\text { to either SARS-CoV-2 } \\
\text { infection or prematurity }\end{array}$ \\
\hline Nayak AH 2020 & 977 & 141 & $\begin{array}{c}134 ; 131 \\
\text { tested }\end{array}$ & $3 / 131$ & 3 & 131 & $2.3 \%$ & $\begin{array}{l}\text { no evidence of } \\
\text { transmission of } \\
\text { COVID-19 infection }\end{array}$ \\
\hline $\begin{array}{l}\text { Woodworth KR } \\
2020\end{array}$ & 4442 & 4442 & $\begin{array}{c}4495 \\
610 \\
\text { tested }\end{array}$ & $\begin{array}{l}16^{*} / 610 \\
\left({ }^{*} \text { timing of }\right. \\
\text { test not } \\
\text { reported) }\end{array}$ & 16 & 610 & $2.6 \%$ & $\begin{array}{l}8 \text { of the infants with } \\
\text { positive test results } \\
\text { were born preterm } \\
\text { ( } 26-35 \text { weeks); all were } \\
\text { admitted to a neonatal } \\
\text { ICU (NICU) without } \\
\text { indications reported. } \\
\text { Among the } 8 \text { term } \\
\text { infants with positive test } \\
\text { results, one was } \\
\text { admitted to a NICU for } \\
\text { fever and receipt of } \\
\text { supplemental oxygen, } \\
\text { one had no information } \\
\text { on NICU admission, and } \\
\text { the remaining six were } \\
\text { not admitted to a NICU. }\end{array}$ \\
\hline Vouga M 2020 & 1033 & 926 & $\begin{array}{c}820 ; 384 \\
\text { tested }\end{array}$ & $11 / 384$ & 11 & 384 & $2.9 \%$ & $\begin{array}{l}\text { obstetric and neonatal } \\
\text { outcomes } \\
\text { did not differ between } \\
\text { positive and negative } \\
\text { patients; comparing } \\
\text { positive women with } \\
\text { severe maternal } \\
\text { outcomes to positive }\end{array}$ \\
\hline
\end{tabular}


medRxiv preprint doi: https://doi.org/10.1101/2021.06.30.21259750; this version posted July 5, 2021. The copyright holder for this preprint (which was not certified by peer review) is the author/funder, who has granted medRxiv a license to display the preprint in perpetuity. It is made available under a CC-BY-NC-ND 4.0 International license.

\begin{tabular}{|c|c|c|c|c|c|c|c|c|}
\hline & & & & & & & & $\begin{array}{l}\text { women with no or mild } \\
\text { adverse outcomes, } \\
\text { showed a significant } \\
\text { increased risk of } \\
\text { preterm birth and } \\
\text { neonatal admission to } \\
\text { the intensive care unit }\end{array}$ \\
\hline $\begin{array}{l}\text { Maraschini A } \\
2020\end{array}$ & 146 & 146 & 149 & $9 / 149$ & 5 & 149 & $3.4 \%$ & $\begin{array}{l}3 \text { admitted to } \mathrm{NICU} \text {, } \\
\text { none developed serious } \\
\text { illness }\end{array}$ \\
\hline Bachani S 2020 & 348 & 57 & 56 & $5 / 56$ & 2 & 56 & $3.6 \%$ & $\begin{array}{l}4 \text { asymptomatic; } 1 \\
\text { symptomatic and } \\
\text { received respiratory } \\
\text { support for } 48 \text { hours. No } \\
\text { deaths }\end{array}$ \\
\hline $\begin{array}{l}\text { Marin Gabriel } \\
\text { MA } 2020\end{array}$ & 185 & 242 & $\begin{array}{c}248 ; 230 \\
\text { tested }\end{array}$ & $11 / 230$ & 11 & 230 & $4.8 \%$ & $\begin{array}{l}\text { none presented with } \\
\text { pneumonia or any other } \\
\text { clinical feature } \\
\text { compatible with } \\
\text { SARS-CoV-2 infection }\end{array}$ \\
\hline Fenizia B 2020 & 31 & 31 & 31 & $2 / 31$ & 2 & 31 & $6.5 \%$ & $\begin{array}{l}\text { all asymptomatic and } \\
\text { healthy }\end{array}$ \\
\hline Anand P 2020 & 69 & 69 & 65 & $7 / 65$ & 7 & 65 & $10.8 \%$ & $\begin{array}{l}6 / 7 \text { asymptomatic, } 1 \\
\text { received respiratory } \\
\text { support (CPAP) for } 48 \mathrm{~h} \text {, } \\
\text { indication: prematurity. } \\
\text { No deaths }\end{array}$ \\
\hline Gale C 2020 & $\begin{array}{c}66 \text { ( } 66 \\
\text { neonates } \\
\text { selected } \\
\text { based on } \\
\text { positivity) }\end{array}$ & 17 & 66 & $2 / 17$ & 2 & 17 & $11.8 \%$ & $\begin{array}{l}\text { all asymptomatic and } \\
\text { healthy }\end{array}$ \\
\hline Tang F 2020 & $\begin{array}{c}20 \text { ( } 20 \\
\text { neonates } \\
\text { selected } \\
\text { based on } \\
\text { positivity) }\end{array}$ & 20 & 20 & $3 / 20$ & 3 & 20 & $15.0 \%$ & $\begin{array}{l}\text { Infection in infant } \\
\text { presumed based on } \\
\text { presence of IgM. } \\
\text { Symptoms not reported. }\end{array}$ \\
\hline $\begin{array}{l}\text { Schwartz DA } \\
2020\end{array}$ & $\begin{array}{c}19 \text { (19 } \\
\text { neonates } \\
\text { selected } \\
\text { based on } \\
\text { positivity) }\end{array}$ & 9 & 19 & $2 / 9$ & 2 & 9 & $22.2 \%$ & $\begin{array}{l}17 / 19 \text { neonates showed } \\
\text { symptoms, including } \\
\text { respiratory distress. } \\
\text { Selected series of } \\
\text { cases. } 2 \text { deaths. }\end{array}$ \\
\hline
\end{tabular}

*based on testing and/or clinical criteria. 